Article

\title{
Analysis of Restructuring the Mexican Electricity Sector to Operate in a Wholesale Energy Market
}

\author{
Juan C. Percino-Picazo *D, Armando R. Llamas-Terres * and Federico A. Viramontes-Brown \\ Tecnologico de Monterrey, School of Engineering and Science, Av. Eugenio Garza Sada 2501, \\ Monterrey 64849, Mexico; f.viramontes@tec.mx \\ * Correspondence: a00824187@itesm.mx (J.C.P.-P.); allamas@tec.mx (A.R.L.-T.); \\ Tel.: +52-222-668-5026 (J.C.P.-P.)
}

\begin{abstract}
This paper analyzes the energy reform that has taken place in Mexico since 2013, driven by steady growth in energy demand and insufficient economic resources. The relevant points in the restructuring process are discussed, shedding light on the impact of recent governmental actions not aligned with the original spirit of the law. This research uses a framework and fundamentals of a well-organized structural process called the textbook model, making a comparative analysis of Mexican reform. It proceeds by presenting the Mexican Electrical System in numbers and how it is affected by the present government's restructuring process providing positive and negative impacts of several implementations. The main objectives of restructuring were carried out to attract private investment and increase the reliability and efficiency of the system. During the first four years, the reform has attracted investment, in diminishing form in generation but not in transmission and distribution. Therefore, the main reason for this is explained and a brief analysis and the roots of these failures are presented. It is shown that recent political decisions tend to keep the system operator and regulatory agencies under Federal Government control so that it is acting against the main objectives of the original reform. Finally, a summary of the deviation of the reality from the existing law is outlined.
\end{abstract}

Llamas-Terres, A.R.; Viramontes-Brown,

F.A. Analysis of Restructuring the Mexican Electricity Sector to Operate in a Wholesale Energy Market. Energies 2021, 14, 3331. https:// doi.org/10.3390/en14113331

Academic Editor: Ricardo J. Bessa

Received: 29 April 2021

Accepted: 2 June 2021

Published: 5 June 2021

Publisher's Note: MDPI stays neutral with regard to jurisdictional claims in published maps and institutional affiliations.

Keywords: electricity sector reform; market restructuring; unbundling; regulatory capture

\section{Introduction}

Since 1980, movements to reform electric power systems have been implemented around the world. The aim was to increase efficiency, improve quality of service and increase electrification. In recent years, other objectives were added, for instance, to reduce greenhouse emissions or increase renewable energy generation. The restructuring process was designed to achieve these goals through competition, price-cost gap reduction, and investment increase [1]. The restructuring process has been documented and condensed in what is called the textbook model; this is a compilation of ten guidelines to achieve the goals above. If fully respected, it increases the possibility to get a highly competitive and unbundled electricity market model [2]. However, the implementation of the textbook model is not applicable as a rule in any country. Still, it should be adapted to the specific country conditions, these being the institutional framework, the country's size, and the social and political characteristics.

In the so-called textbook model, the government's non-intervention in the activities of the electricity industry is suggested [2]. However, in practice, there is always participation on the part of the government, from the undisputed power to dictate the country's energy policy, through to the control of the effects of fuel prices on final rates, the assurance of supply, the mitigation of climate change, going as far as maintaining preferential rates for specific sectors of the population or looking after the interests of particular groups [3]. Electricity supply has been a public and universal service, making the State ultimately responsible. 
In Mexico, for many years during the last century, electricity supply was carried out under a vertically integrated monopoly scheme, operated, and owned by the State. The enactment of the Electricity Industry Law in 1939 [4] considered as main goals the activities regulation of the electricity sector in order to promote country development for the benefit of the collective [4]. In 1975, the Electricity Industry Law was abrogated and replaced by the Ley del Servicio Público de Energía Eléctrica (LSPEE), the Public Electricity Service Law, which reserved the electricity sector exclusively to the State but allowed self-consumption for non-public service [5]. In 1992, private participation was extended to other modalities such as self-supply (different from self-consumption), cogeneration, small production, import, export and independent power producer (IPP). This one with entire electricity production for Comisión Federal de Electricidad (CFE), the State company [6]. The objectives from 1975 to 2013 were to supply electricity with criteria of sufficiency, competitiveness, sustainability, and customer satisfaction $[5,6]$. However, the situation before 2013 demonstrated the following problems: one percent of the population did not have electricity service, the non-competitive tariffs were higher than those in the United States, and were insufficient to cover production costs, the State company indebtedness increased substantially, technical and non-technical losses grew, investment in the power sector was too low and high labor liabilities were observed [7].

A restructuring process was required to solve these problems. Such a process began in 2013, with the reform of the Constitución Política de los Estados Unidos Mexicanos, the Mexican Constitution, to allow private investment in competitive activities, such as generation and commercialization and the possibility of private participation in joint ventures with CFE in transmission and distribution [8]. The objective was to lay the wholesale energy market model's foundations and provide a safe, reliable, universal, clean, and price cost-reflecting service [9]. The Mexican power sector reform was designed and implemented in President Peña Nieto's (2012-2018) administration as part of a more general energy reform that included the oil and natural gas sectors. Nevertheless, President López Obrador's administration (2018-2024) has placed an administrative blockage to the energy market-oriented reform. His energy policy endorses and promotes vertical integration of the electricity sector led by the State company CFE, supported by the Secretaría de Energía (SENER), the energy ministry, and the Comisión Reguladora de Energía (CRE), the regulation agency [10]. The effects of taking the electricity market structure back into a vertical integration have led to market distortion, uncertainty, and diminishment in private investment.

In the literature, there are several works related to the restructuring process of the Mexican power sector. Alpizar [11] describes, in 2016, the reform process of the electricity and hydrocarbon sectors, as well as the State's objectives to promote such restructuring: to encourage more active private participation in the energy sector, reduce energy tariffs, correct the finances of the State electricity productive companies, and move towards a cleaner generation matrix. Ibarra [12] analyzes, in 2015, the restructuring process of the electricity reform and points out that the unbundling and vertical separation of the electricity industry segments was not complete. The government over-regulation could sway power sector failure. He compares the main characteristics and attributions of the independent system operator (ISO) from California, Texas, and Mexico, finding weaknesses and strengths. Zenón [13] evaluates, in 2016, the expansion of the transmission system under the market scheme and finds that it is compatible with the Programa de Desarrollo del Sistema Eléctrico Nacional (PRODESEN), the official power system planning program, published by SENER. Kunz [14] addresses financial transmission rights (FTRs) under a nodal price optimization model and shows that the benefits of FTRs can be exploited with the impulse of policies that support them. To the best of our knowledge, the administrative blockage of the Mexican power sector reform has not been studied in previous works.

This paper aims to assess the performance of the Mexican power sector under the restructuring process (2013-2018) and its recent hindering (2018-2021). The contributions of this paper are two-fold. Firstly, this paper analyses whether the power sector reform 
was well designed for solving the problems that existed before 2013. It uses a theoretical framework based on the textbook model to determine whether the lack of results is caused by the limitations of the restructuring design of 2012-2018 or by the recent political capture of 2018-2021. Secondly, it contributes to the discussion about the actions that should be considered by the policymakers, aiming at continuing with the reform process towards the consolidation of a competitive and clean energy market. The lessons learned from the Mexican restructuring process can provide valuable insight for developing countries with a strong governmental influence in their power sector reform.

The document's structure is as follows: Section 2 presents the conditions that gave rise to the restructuring process and the theoretical framework mainly from the textbook model and the critical characteristics of an independent regulatory agency. Section 3 describes the Mexican power sector and the conditions of the sector before the reform. Section 4 discusses the reform progress and the setbacks from 2013 to 2021 . Section 5 discusses the main findings and the deviation from the original law. Section 6 concludes.

\section{Theoretical Framework}

\subsection{Why Restructure?}

Restructuring is a reorganization of the activities, rights, obligations, and responsibilities of the electricity industry stakeholders, as well as a rearrangement of the ownership of assets and the redesign of regulation [15]. Most of the structural reforms in the world have been based on a vertically integrated industry formed by private or State-owned monopolies under a highly regulated scheme. Taking advantage of the benefits and scope of economies of scale with access to low-cost capital, significant progress was made in the electrification and construction of new power generation plants, improving reliability levels while keeping reasonable energy prices. Electricity service regulation was working satisfactorily. However, cost-based regulation, although it guarantees cost recovery for companies, does not encourage cost minimization. Thus, the problems of inefficiencies and lack of incentives to minimize costs and introduce technology innovation were seen [15].

Although operating inefficiencies and economic losses occurred in many countries, some authors differentiate the problems between developed and developing countries. For developed countries, operational inefficiencies, such as low labor efficiency, high operating costs, cost overruns in the construction of new infrastructure, expensive electricity tariffs, low levels of reliability, safety, high levels of indebtedness of the incumbent company, and excessive installed capacity were observed [16,17]. In developing countries, large technical and non-technical losses in transmission lines, supply interruptions or blackouts, crosssubsidy policies, the establishment of below-cost tariffs, high levels of indebtedness of the incumbent company, and lack of investment in the power sector were observed [18,19]. In addition to the problems of an inefficient monopoly, other factors influenced the restructuring of the sector, such as the reform process in telecommunications, air transport, and railroads sectors, and the pressure from the World Bank and the International Monetary Fund [20]. Technological factors, such as the development of the small-capacity gas turbine and the development of telecommunications technologies, were important in the reform process of the electricity sector [15].

In the case of the Mexican electricity system, the problems mentioned earlier became evident: generation costs rose substantially, non-competitive tariffs compared to those in the United States, high State company indebtedness, high labor union liabilities, trade unions reluctant to change the status quo, high technical and non-technical losses, and lack of investment resulted in blackouts or power outages [7]. Additionally, positive factors help the transition to a power market structure. Large-scale combined cycle technology offered an efficient, cost-effective alternative, with shorter construction time, higher efficiency, low-cost, and abundant inexpensive natural gas from the United States.

In general, a successful application of the textbook model would solve problems such as capital solvency for new infrastructure, encourage competition to offer lower prices by increasing efficiency, reduce power losses, improve universal access to the service, and 
increase the security and reliability of the system [21]. However, the market model itself has its specific problems that, if not adequately addressed, can result in a model even worse than the vertically integrated system [22]. Thus, it is necessary to integrate into the reform the elements that correct the initial problems and address the complexities of the market.

\subsection{Textbook Model and International Experience}

Power sector restructuring is an evolving process guided by technological evolution, geographic expansion of markets, implementation of green policies, optimization mix of generation fleet, storage, demand-side resources, and transmission infrastructure $[23,24]$. Experts and academics documented the main ideas of the restructuring process in many countries. Vertical unbundling of the power sector, privatization, competition, and introduction of agency regulation were the first ideas presented [25]. Later, other authors considered non-discriminatory open access, horizontal integration of transmission, and system operation as essential [26,27], and by the 2000s, versions of the textbook model were pretty similar.

Some countries with extensive experience in reforming their electrical system have implemented advanced reform steps. Fotouhi et al. [28] present the experience of retail electricity market liberalization in Portugal. They show that liberalization allows for the implementation of small user demand response. Although incumbents could maintain a dominant market position, users have a more comprehensive range of options. Hartley et al. [29] review the relationship from 2002 to 2016 between retail and wholesale prices in competitive and non-competitive regions in Texas. They found that, in competitive regions, the retail prices reflected the wholesale prices at the end of 2016. However, in non-competitive regions, great political control and low competition increase the gap between prices and marginal costs; moreover, the cross-subsidization of residential by commercial customers was found in non-competitive areas. Shin and Managi [30] examine the liberalization of the retail electricity market in Japan in 2016. They observed a good rate of customers switching. Additionally, the results indicate a reduction in the utility bill as an incentive to retain customers.

In developing countries, the reform process is quite different. The technical, structural, political, economic, and cultural characteristics and the institutional framework are significantly different from those in developed countries. Literature review about these emerging countries shows many different restructuring configurations. Urpelainen and Yang [31] present a dataset of 142 developing counties from 1982 to 2013 that started a power sector reform. They show that most of the countries do not apply a full textbook reform but a hybrid one because of the lack of formal institutions, low income, and the reluctance of governments to relinquish the political control of the power sector.

Moreover, Bensch [32] explains that power sector reform is not the panacea itself. Bensch analyses 70 qualitative and quantitative studies to measure the effects of privatization, liberalization, private sector involvement, and regulation over different indicators expected to improve after power sector reform: efficiency, supply and investment, and cost/tariff ratios. Even though the results were not conclusive, the reform process did not have the positive expected results in some cases. Ponce-Jara et al. [33] present the evolution of the electricity sector in Ecuador from 2007 to 2017. They show that the legal framework was modified in 2015 to move the generation fleet towards a cleaner energy matrix and the incorporation of new technologies such as smart grids; therefore, the amendment also reinforced the State's position in the electricity sector as the sole institution in charge in critical activities, but joint ventures with private companies were allowed. In addition, distribution losses were significantly reduced. Mastropietro et al. [34] present the issues in the Colombian short-term electricity market by implementing single non-binging settlements and the clearing of hourly marginal prices for the entire system. They argue that a multi-settlement system allows for better reflecting remuneration for flexible units when more renewables are included. Daglish et al. [35] analyze the pricing effects of the electricity market reform in Brazil from 1998 to 2004. They show that the marginal wholesale prices 
were reduced at the beginning, but they saw a probability increment in the last years of crises occurring. Additionally, they show that volatility price is reduced during normal times, but in times crisis became more severe.

The experience of restructuring power systems has shown that the textbook model is currently applied in developing countries, although hybrid implementations are very common. A complete version of the textbook model is the following [18]:

1. Separate segments vertical to the electricity industry, structurally (unbundling) or functionally (internal walls or rings, separating subsidiaries within the same organization).

a. It creates a competitive segment of the electricity industry (generation, commercialization).

b. It creates regulated segments (transmission, distribution, system operation).

c. It avoids cross-subsidies among state companies.

d. It allows for advanced regulation when the number of participants increases.

2. Privatize the State's assets in the electricity industry.

a. It encourages improvement in the performance of the companies.

b. It hinders the use of these companies in favor of costly political agendas.

c. Increases the possibility of private investment, reducing the risk taken by the State in electricity projects, allowing the State to invest in other sectors.

3. Restructure the generation sector horizontally.

a. It creates many competitors to avoid market power and ensures that the wholesale energy market will deliver significant competitive results.

4. Integrate the system operation, transmission, and distribution horizontally.

a. It unifies system operation, centralizes unit dispatch, and maintains frequency, voltage, and stability parameters within their ranges.

5. Create an ISO to manage the voluntary wholesale energy market.

a. It expands competition, facilitates economic transactions among market participants, and minimizes the regulator's intervention in the wholesale energy market.

6. Enforce regulatory rules supporting open access to the power grid.

a. It guarantees open and non-unduly discriminatory access to networks.

7. Itemize retail tariffs for captive consumers.

a. It differentiates the regulated tariff items from market items and allows the consumer to choose among suppliers.

8. The supplier of small captive users must purchase energy in the wholesale energy market.

9. Create an independent regulatory agency.

a. With a good knowledge of costs, quality of service, and performance of transmission and distribution companies.

10. Create transition mechanisms compatible with a well-designed market.

a. Pre-existing pricing arrangements for captive users before they migrate to the retail market.

Latin American countries showed that electricity reforms were implemented without adequate independent institutions and the public sector was not strengthened to deal with the private sector [36]. Joskow [37] warns that the assumption of a robust institutional framework for successful restructuring has been considered costless and without operational problems. The establishment of private property rights, contract enforcement, effective dispute resolution, sound capital markets, and corporate governance systems are some of the examples pertaining to the institutional framework [21,36,37].

For more than 30 years, developed countries that followed the textbook model had successful reforms [18]. Most of the time, in developing countries with incomplete reforms, 
according to the textbook model, their problems were also a consequence of the pre-reform conditions of each country.

\subsection{Regulation}

According to point 9 of the textbook model, it is essential to establish a single and independent body to regulate the activities of the electricity industry impartially in the public interest. Its activities should not overlap with those of other institutions. The main objective of the regulator is to establish mechanisms to correct signal failures, reduce government intervention and increase the credibility of restructuring the industry [38]. Besides, the regulatory framework's evolution is necessary to integrate different technologies that could not be integrated with the appropriate rules. It is necessary to separate the regulator from the ministry of energy, mainly when the State retained a monopolist role in the networks as a market participant after the reform. Therefore, the regulator must be independent of the regulated parties, the federal government, the parliament and must have the competence to regulate.

The main functions of the regulator are: to guarantee open, non-discriminatory access to the networks; to oversee and encourage the efficient operation of sectors that operate under regulated tariffs; to establish tariffs; to design mechanisms to ensure a long-term supply of generation resources; to provide protection to small consumers; to follow up and resolve disputes between regulated entities; to monitor the market and prevent abuse of market power; to promote good practices and understanding of regulation; to require compliance with the regulatory framework [39].

The regulatory body must be an institution that, in the long term, generates stability and continuity. Its decisions must be based on criteria of rationality, fairness, and impartiality, listening to all parties, but at a considerable distance. That is why it must have appeal mechanisms, public hearings, and well-defined procedures and rules to execute its activities. The regulator's practices should be carried out under transparency and accountability, avoiding discrimination, and generally following good governance practices.

In practice, no regulator satisfies every one of the characteristics mentioned above or performs all activities. There are many problems due to non-compliance with activities, noncompliance with conditions of activities, or simply the characteristics of the environment. For instance, asymmetric information among the regulator and the regulated parties may hinder its performance [40]. The regulator's staff are required to be highly specialized. Thus, sometimes the desirable profiles are not met; some activities may be assigned to the area of the federal trade commission, the treasury, or even a consumer protection agency and are duplicated.

In some cases, the regulator comes from a federal government agency and depends on it. It is highly complicated to establish total independence from both the federal government and the regulated market, and they may be prone to regulatory capture. Regulatory capture is understood as the process through which the participants of a regulated monopoly end up manipulating the government agencies that are supposed to control them [41]. It is not common to find a definition that includes the government as a captor of the government agencies themselves, in which case one speaks of political capture [42].

Some authors have developed methodologies to assess the independence of the regulator $[39,43]$. Gilardi developed a regulatory independence index based on four main points: independence of the agency head, independence of the commissioners, independence from government and parliament, and financial and organizational independence. In addition, it is relevant whether the regulator performs their duties in complete independence or whether another entity influences it. The index evaluates these points on a zero to one basis, where zero represents very low autonomy and independent decisions, and one represents greater autonomy and independence of decisions [39]. 


\section{Restructuring of the Mexican Electricity Sector \\ 3.1. Background}

Three systems integrate the Mexican National Electric System (SEN), the isolated electric system in Baja California Sur, the electric system of Baja California interconnected to the Western Electricity Coordinating Council in the United States, and the National Interconnected System (SIN). This work focuses the analysis on the SIN and excludes the Systems of Baja California. The electricity consumption in the SEN has primarily relied on fossil fuels. The electricity mix accounts for over $75.22 \%$ coal, oil, and gas in the whole period 2000-2020. However, gas-fired power plants have increased electricity production, reaching almost $60 \%$ of the mix in 2020 [44]. Notice that hydro is the predominant renewable source, but the wind increased electricity production since 2010, followed by photovoltaic solar power plants. In 2020 clean energy production accounted for almost $24.77 \%$, which includes wind, solar, hydro, nuclear, other renewables defined in the Electricity Industry Law (LIE) (LIE, Art. 3, XXII) [9]. Figure 1 shows the electricity production of the last twenty years by generation technology. The tendency is increasing in almost the whole period. Meanwhile, in 2020 the COVID-19 pandemic event significantly reduced economic activity, impacting electricity production in the whole country.

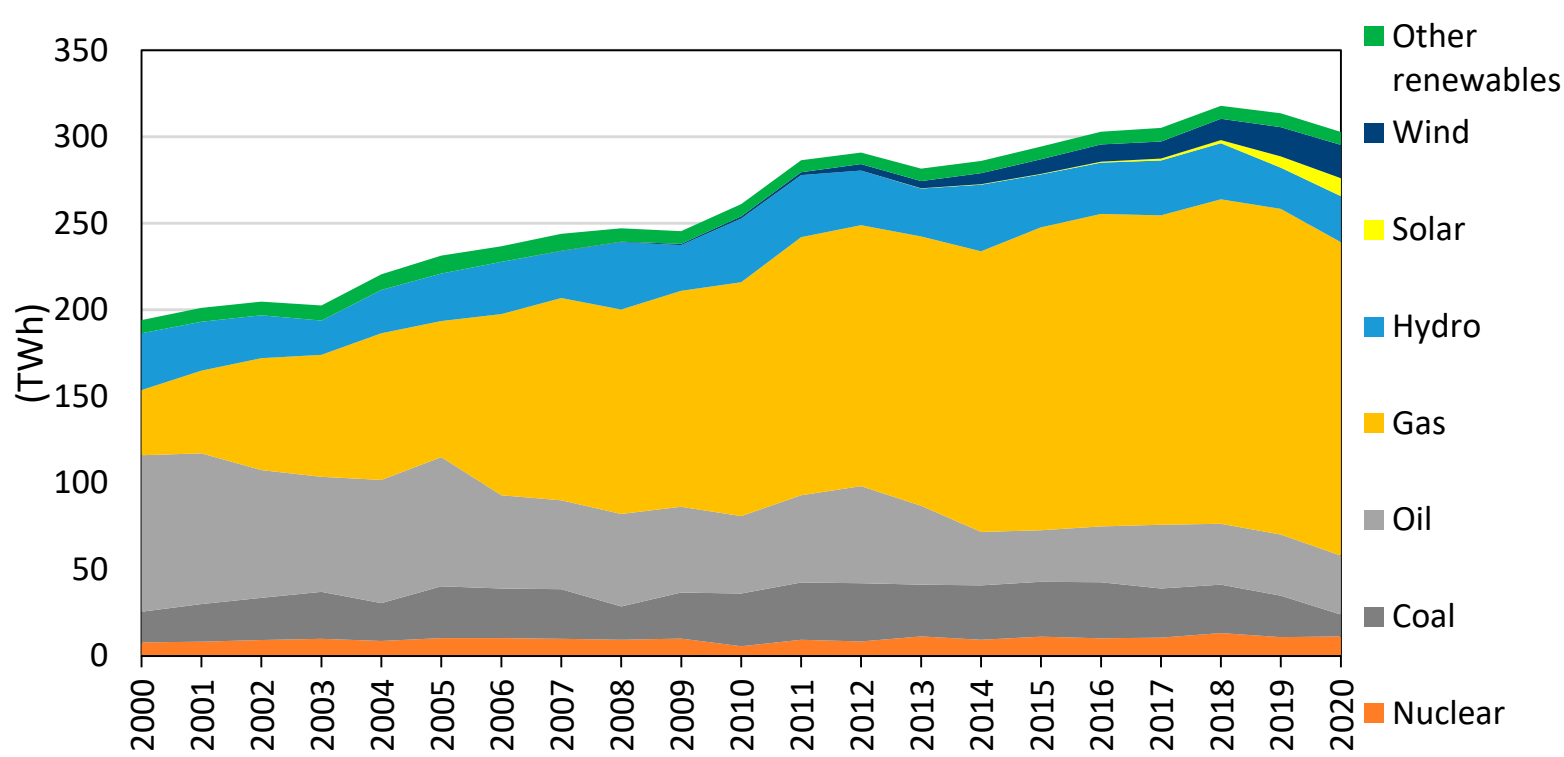

Figure 1. Electricity production in the Mexican power system by source in the period 2000-2020.

The electricity sector was opened to private participation in 1992. Due to its participation in the North American Free Trade Agreement, the appropriate modifications were made to the Public Electricity Service Law in 1992 to allow for the participation of private investments, under the following modalities: self-supply, cogeneration, independent power producer (IPP), small production, import and export of electricity [45]. However, the problems inherent to a vertically integrated industry began to manifest, as explained in Section 2.1. In 1995, due to the lack of investment capital, the financing schemes called Productive Infrastructure Investment Projects with Deferred Registration in Public Expenditure (PIDIREGAS) were implemented. This scheme allowed the federal government to carry out projects with resources from the private sector and amortize interest and capital payments with the income from the constructed projects. PIDIREGAS are subdivided into two categories: direct investment, under the Build, Lease, Transfer scheme, and conditional investment, Build, Own, Operate, which is the scheme of IPP projects [46].

Although private participation helped build generation plants to meet the growing demand, other problems have surfaced, such as applying subsidies to specific tariffs. To show this behavior, we took the price/cost ratio where a value less than one means tariffs below production cost, and a value greater than one reflects tariffs above production cost, 
on a yearly average basis. Figure 2 shows that between 2000 and 2014, agricultural and residential tariffs were highly subsidized with an average price/cost ratio of 0.3 and 0.4 , respectively [47]. Notice that commercial and large industry tariffs were lesser subsidized, with ratios around 0.9; subsequently, their ratios increased to 1.16 for both tariffs in 2014.

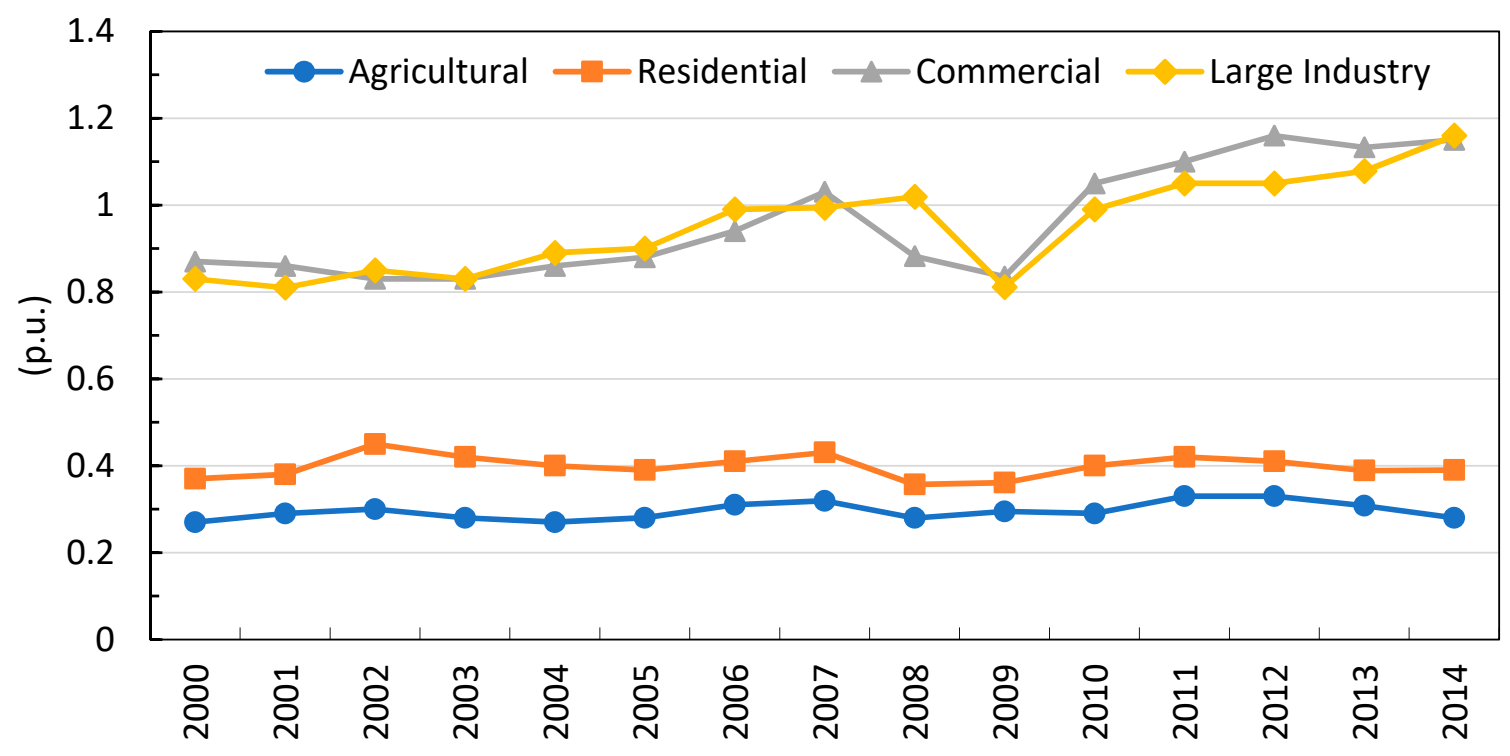

Figure 2. Price/cost ratio of representative tariffs.

Figure 3 shows that in correspondence with the inadequate price/cost ratio, especially for agricultural and residential tariffs, subsidies granted by the Federal government corresponded to USD 5572 million (all currency units are 2015 constant American dollars) in 2000, and in 2014 subsidies reached the amount of USD 7378 million [47]. The residential sector received $74 \%$ of the total subsidies in 2000 and reached $88.35 \%$ in 2014 . It is also observed that commercial and large industry tariffs stopped receiving subsidies in 2010 and 2011, respectively.

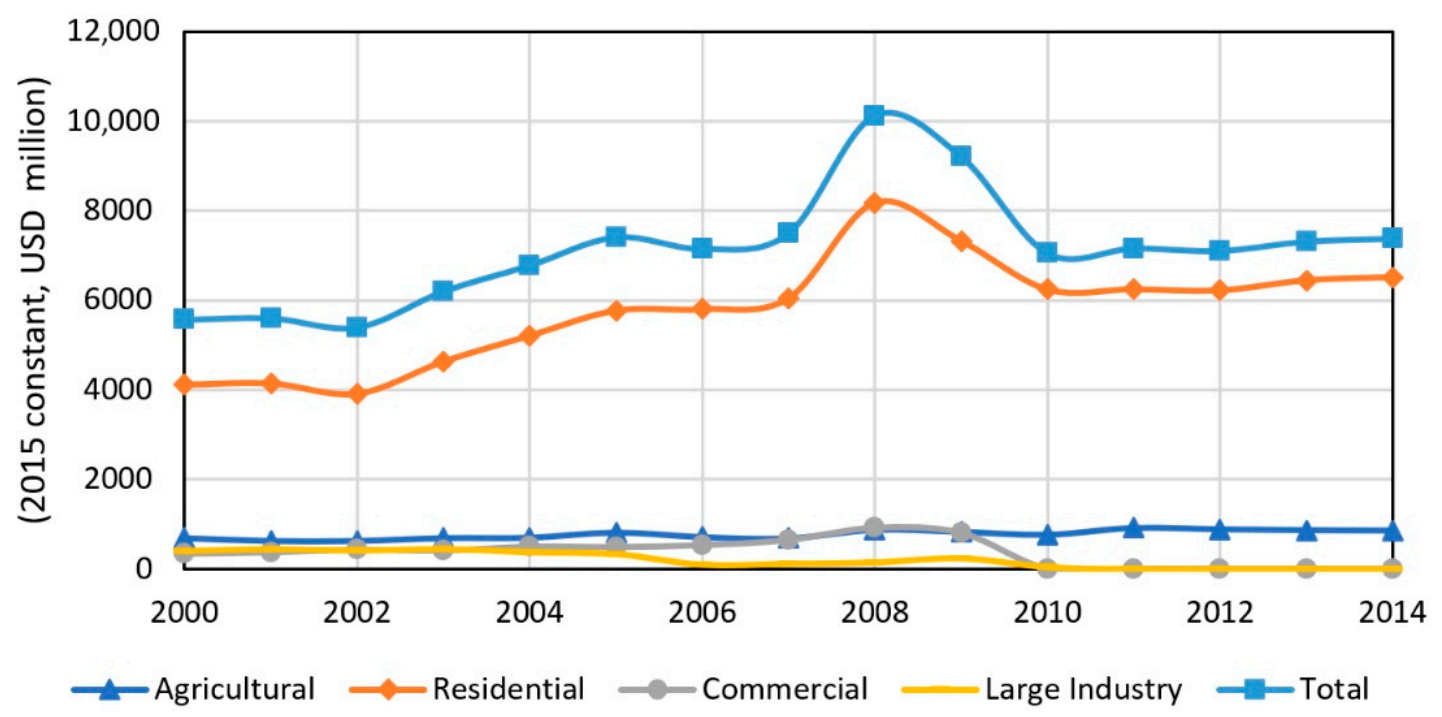

Figure 3. Subsidies granted by tariff (2015 constant, USD million).

According to data from the Auditoria Superior de la Federación (ASF), the Federal Superior Audit Office, the total amount of subsidies was not always covered by the federal government, and the missing amount was charged to the finances of the CFE. Therefore, impacting the loss of CFE's equity. Figure 4 shows how equity fell between 2006 and 
2015. In 2006, equity represented $51 \%$ of assets, while in 2015 , it was only $10 \%$ [48-52]. As a result of the renegotiation of CFE's labor liabilities and the federal government contribution of USD 8296 million, equity recovered significantly in 2016. Additionally, assets increased from 2015 to 2017 because CFE assets were positively re-evaluated after restructuring $[53,54]$. Nevertheless, the company's liabilities have been increasing.

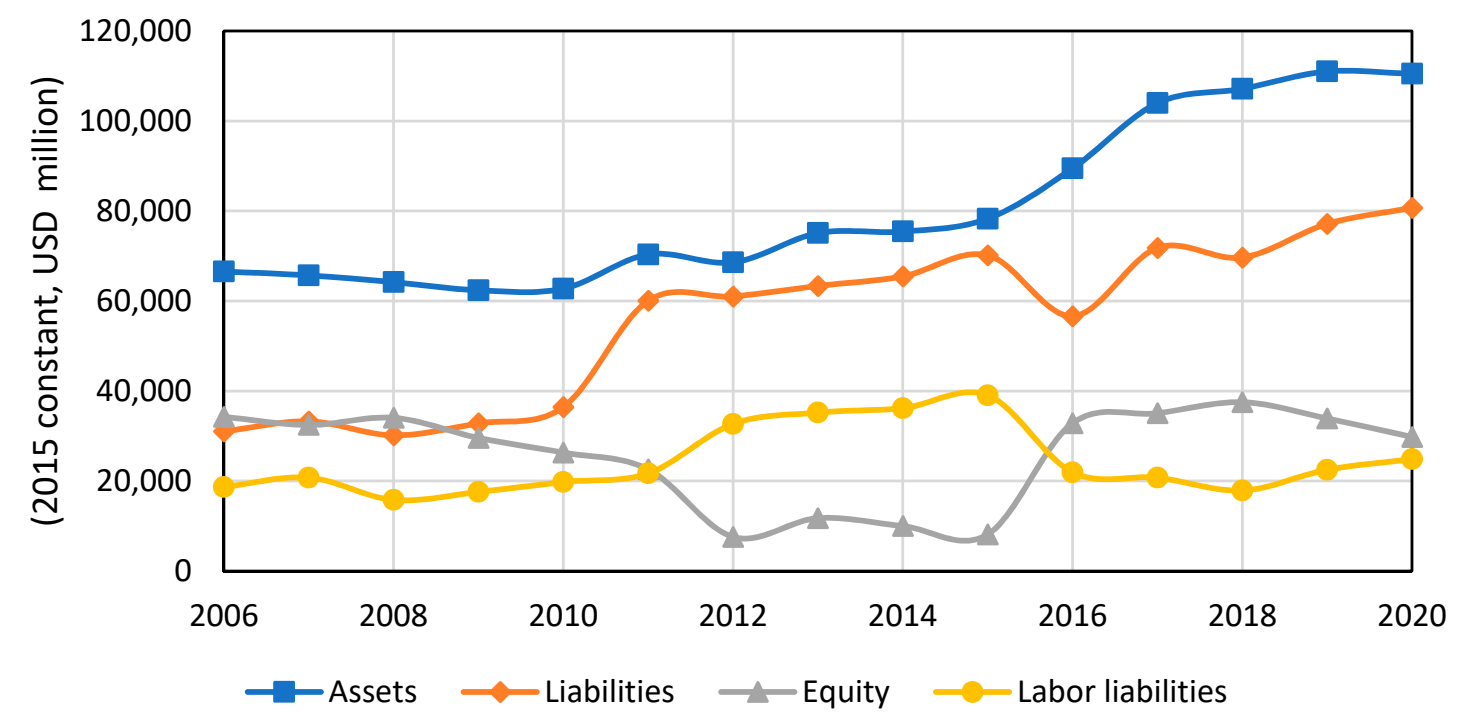

Figure 4. CFE's equity in the period 2006-2020.

On the other hand, Figure 5 shows that installed capacity has always been greater than maximum demand [47,55], mainly because the loads are geographically dispersed, with transmission grid limitations requiring more generation capacity to manage contingencies. Even though the capacity/demand ratio ranges between 1.5 and 1.72, a fraction of this capacity was unavailable. This statement is reinforced by the fact that, for several years, the operating reserve margin (MRO) was less than the recommended $6 \%$. The unavailability of power plants is related to the aging of the plants. The critical natural gas alerts in 2012 restricted the use of gas in the industry due to a shortage in supplies [55].

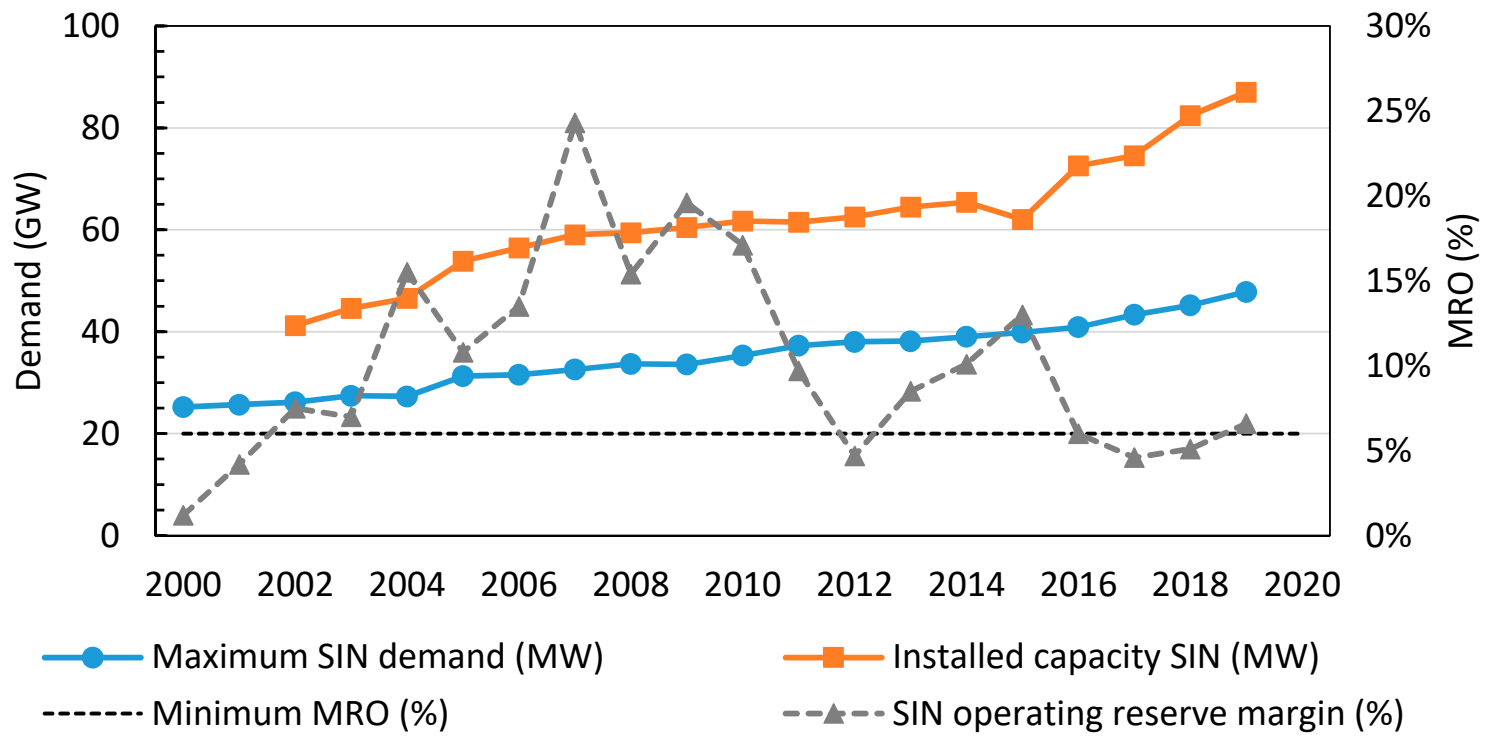

Figure 5. Installed capacity and operating reserve margin 2000-2019.

Considering the presented arguments, the Mexican electricity industry had severe structural problems reflected in heavy tariff subsidies and the compromised finances of 
the CFE. These problems avoided investment in new infrastructure to meet the growing demand at reasonable prices, secure, reliable, and sustainable way, without detriment to the CFE's equity.

\subsection{Restructuring Process}

As explained in the previous section, the problems that prevented a vertically integrated public monopoly model from meeting the demand with the required characteristics worsened in the Mexican electricity industry. That is why, in 2013, Articles 25, 27, and 28 of the Mexican Constitution were reformed [8]. Later, in 2014, secondary laws were approved, the LIE, the Geothermal Energy Law, the Law of the Federal Electricity Commission (LCFE), and the Law of the Coordinated Regulatory Bodies (LORCME), among others [9,56]. In the Mexican Energy Reform, nine laws were created, and twelve were modified, creating the legal framework to restructure the electricity and oil sectors, allowing private participation in competitive areas, and beginning the liberalization of the retail market.

Before power sector restructuring, the State owned and operated the entire power sector through the incumbent company, but private generation was allowed for self-supply and entire power production to CFE [45]. After the LIE enactment in 2014, two parallel regimes were allowed: a so-called "legacy" or "grandfathered" regime, granting vested rights to permit holders under the LSPEE law; and the "electricity market" regime, which is subject to competition in liberalized activities and regulated by tariffs in monopoly activities as LIE establishes [9]. Under the electricity market regime, CFE activities were vertically unbundled as follows [57]:

1. Generation.

2. Transmission.

3. Distribution.

4. Basic Supply.

5. Commercialization other than Basic Supply.

6. Primary Fuels Supply.

To promote an efficient market performance and avoid market power, generation was horizontally unbundled into six subsidiaries, CFE Generacion from I to VI. The legacy contracts IPP for entire power production to CFE are administered by CFE Generacion $\mathrm{V}$. The rest of the grandfathered contracts are administered by CFE Intermedición de Contratos Legados (ICL). Regardless of the incumbent company's vertical and horizontal unbundling, no divestiture or privatization of any CFE subsidiaries' assets occurred. Even though it was not privatized, it is essential to notice that divestiture increases the possibility of private investment, reducing the risk taken by the State in electricity projects and allows the State to invest in other sectors. It is even worth pointing out that vertical unbundling is crucial before privatization. If it is not unbundled, the result would be a private monopoly, even worse than a State monopoly.

According to the LIE, it can be observed that Mexico carried out a reform following the textbook model. Of the 10 points, 9 of them were established and implemented almost fully-these were:

1. Vertical separation of the power sector activities.

2. Horizontal restructuring in the generation sector.

3. Horizontal integration of system operation, transmission, and distribution.

4. The Centro Nacional de Control de Energía (CENACE) was created as an ISO to operate the voluntary wholesale energy markets.

5. Regulatory Rules supporting network non-discriminatory access.

6. Creation of an independent regulator.

7. Itemization of retail tariffs for captive consumers in order to highlight the regulated tariffs and to allow the consumer to choose among suppliers without incumbent affection.

8. The supplier of small captive users must acquire power in the wholesale energy market and long-term auctions.

9. Transition mechanisms compatible with a well-designed market. 
At the time of implementing the electricity sector reform, rule two of the textbook model was not implemented because State assets were not privatized. However, the LIE allows for the divestiture of assets if necessary (LIE art. 9). Among other issues, risk mitigation mechanisms for congestion, such as FTRs, were left pending, with the exception of legacy FTRs [58].

In the LIE, the government was allowed to influence, through different committees, in a direct manner over relevant aspects that affect the performance of the electricity market. The first element that stands out is the federal jurisdiction overall activities of the electricity industry (LIE art. 7), leaving coordination with the states and municipalities only for rural electrification (LIE art. 113). Among the direct attributions of the federal government is naming the director of the state productive enterprise CFE (LCFE art. 46), as well as the appointment of the members of the board of directors of the CFE: three directors from the federal government and four independent directors ratified by the Senate (LCFE art. 14). In the case of the members of the Regulatory Agency CRE, as well as the president commissioner, the Senate of the Republic is responsible for the appointment upon the proposal of the federal government (LORCME art. 6). However, if the proposed candidates are rejected by the Senate, the federal government has the power to make direct appointments. Likewise, the federal government also reserves the right to determine tariffs for specific groups of basic supply users (LIE art. 139).

As strategic areas, the State reserves for itself the planning and control of the SEN and public service of transmission and distribution (LIE art. 2). Likewise, the State establishes and executes the policy, regulation, and surveillance of the electricity industry, through the SENER and the CRE (LIE art. 6).

The SENER is considered an authority (LIE Cap. II), and among its attributions are (LIE art. 11):

1. Establish the required terms of strict legal separation or otherwise order the divestiture of assets to promote open access and efficient operation of the electricity sector (LIE art. 8 and 9).

2. Establish, conduct and coordinate the country's energy policy.

3. Prepare and issue documents for the development of the electricity industry.

4. Ensure the coordination of the CENACE, the National Natural Gas Control Center, the regulator CRE and other authorities relevant to the electricity industry.

5. Evaluate in coordination with the CRE the performance of CENACE.

6. Resolve social impact assessments of projects related to the electricity industry.

7. Establish requirements and criteria for acquiring and granting Clean Energy Certificates.

8. Prepare, coordinate and instruct infrastructure projects to comply with the country's energy policy.

9. Authorize the programs and instruct the expansion and modernization projects of the National Transmission Network and the General Distribution Networks, to the transporters, distributors or private companies.

10. Verify compliance with the LIE, its regulations, rules and other applicable provisions.

11. Investigate, denounce, and impose sanctions corresponding to its attributions (LIE art. 162).

12. Determine the reliability and safety policy of the SEN (LIE art. 132).

13. Request information and facilitate the transparency of the wholesale energy market (LIE arts. 158 and 159).

In relation to CENACE, it should be noted that, despite being a decentralized public agency of the Federal Public Administration, with its own legal personality and assets (LIE art. 107), the fifth transitory provision of the LIE establishes that it is an agency that reports to SENER.

The State is responsible for determining energy policy and intervening in the activities of other participants in the electricity industry. Its multiple roles become evident, which may affect its performance due to the possible conflicts of interest. The designers of the 
energy reform left broad capabilities to the Head of the Federal Government (nation's president), so the degree of intervention may be significant [59].

\section{Electricity Reform: Progress and Results}

After the publication of the secondary laws in 2014 and the start of operations of the wholesale energy market in January 2016, it can be said that the evaluation period of the electricity reform was very short. Table 1 shows the available capacity by generator modality. Before market reform, private participation in generation was represented by IPP and ICL. Legacy installed capacity increased slightly after sector reform because CRE granted legacy permits until 2014. In contrast, new market participants represented by generators were responsible for a small share of total capacity, $0.52 \%$ in 2016 and $11.82 \%$ in 2020 [60].

Table 1. Capacity available for energy production per market participant from 2016 to 2020.

\begin{tabular}{cccccc}
\hline & \multicolumn{5}{c}{ Verifiable Capacity (MW) } \\
\hline Market Participants & $\mathbf{2 0 1 6}$ & $\mathbf{2 0 1 7}$ & $\mathbf{2 0 1 8}$ & $\mathbf{2 0 1 9}$ & $\mathbf{2 0 2 0}$ \\
\hline CFE & $37,279.07$ & $38,597.53$ & $39,368.33$ & $38,913.34$ & $38,798.70$ \\
\hline IPP & $12,464.35$ & $12,554.65$ & $12,555.65$ & $13,470.39$ & $15,263.97$ \\
\hline ICL & 7853.00 & $10,462.73$ & $10,444.19$ & $11,616.16$ & $11,861.43$ \\
\hline Generators & 298.40 & 1200.61 & 2326.56 & 5553.86 & 8833.88 \\
\hline Total & $57,894.82$ & $62,815.51$ & $64,694.72$ & $69,553.75$ & $74,757.98$ \\
\hline
\end{tabular}

On the supply side, the reform specified two modalities of market participants. Qualified suppliers are load-serving entities supplying load centers with a demand equal to or higher than $1 \mathrm{MW}$, and Basic Service Suppliers for retail load centers with demand lower than $1 \mathrm{MW}$. Before implementing the wholesale energy market, the legacy contracts were almost $13 \%$ of the total demanded capacity in the Mexican power system, and they slightly increased their demand in the next five years. After the wholesale energy market started operations, qualified suppliers increased from zero MW in 2016 to 1336.38 MW in 2020; however, it only represented $3.39 \%$ of the total. On the other hand, CFE Basic Service Supplier was responsible for the most demanded capacity. In 2016, it was $87.07 \%$, and in 2020 it accounted for $81.04 \%$ of the total [61]. Market participation is increasing, but the CFE basic service supplier is still the preponderant participant (see Table 2).

Table 2. Demanded capacity per market participant from 2016 to 2020.

\begin{tabular}{cccccc}
\hline & \multicolumn{5}{c}{ Demanded Capacity (MW) } \\
\hline Market Participant & $\mathbf{2 0 1 6}$ & $\mathbf{2 0 1 7}$ & $\mathbf{2 0 1 8}$ & $\mathbf{2 0 1 9}$ & $\mathbf{2 0 2 0}$ \\
\hline CFE basic service supplier & $33,858.57$ & 35,015 & 36,865 & 36,733 & 31,987 \\
\hline ICL supplier & 4963.14 & 5768.29 & 5780.05 & 5740.96 & 5940.99 \\
\hline Qualified supplier & 0.00 & 121.27 & 186.98 & 546.37 & 1336.38 \\
\hline Generators & 64.21 & 86.98 & 182.60 & 215.56 & 206.17 \\
\hline Total & $38,884.92$ & $40,991.97$ & $43,014.71$ & $43,235.69$ & $39,470.38$ \\
\hline
\end{tabular}

Some relevant results show the imperative need for large amounts of required investment for the different activities of the industry. In 2018, the PRODESEN calculated an expected investment of USD 104,123 million in the next 15 years, $84 \%$ in generation, $9 \%$ in transmission and $7 \%$ in distribution [62]. The following are some areas of opportunity for the Mexican Electricity System.

In the case of transmission lines, the increased percentage of losses is an indicator of insufficiency. Table 3 shows the consistent increase, year by year, of electrical losses. The 
losses went from $1.58 \%$ in 2013 to $2.71 \%$ in 2019 [63]. A quadratic trend in losses (\%Loss) were adjusted as a function of the received energy $\left(E_{r}\right)$, with a coefficient of determination $R^{2}=0.94$., i.e., the energy losses change with the square of the received energy, and they could increase in future years according to (1).

$$
\% \text { Loss }=10^{-10}\left(E_{r}\right)^{2}-5 E_{r}+6.53
$$

Table 3. Transmission electricity losses, 2013-2019.

\begin{tabular}{ccccc}
\hline Year & $\begin{array}{c}\text { Energy Received } \\
\text { (GWh) }\end{array}$ & $\begin{array}{c}\text { Energy Delivered } \\
\text { (GWh) }\end{array}$ & $\begin{array}{c}\text { Lost Energy } \\
\text { (GWh) }\end{array}$ & Lost Energy (\%) \\
\hline 2013 & $253,805.8$ & $249,787.4$ & 4018.4 & 1.58 \\
\hline 2014 & $260,398.3$ & $256,262.4$ & 4135.9 & 1.59 \\
\hline 2015 & $265,350.2$ & $261,075.7$ & 4274.5 & 1.61 \\
\hline 2016 & $273,020.1$ & $268,550.2$ & 4469.9 & 1.64 \\
\hline 2017 & $301,150.5$ & $293,423.8$ & 7726.7 & 2.57 \\
\hline 2018 & $311,126.5$ & $303,352.7$ & 7773.8 & 2.50 \\
\hline 2019 & $317,909.0$ & $309,299.9$ & 8609.1 & 2.71 \\
\hline
\end{tabular}

This increase in the percentage of transmission losses highlights an over-utilization of the grid, indicating that not enough has been invested. In the Mexican power system, there are about 2500 nodes setting up locational marginal prices. For convenience, they are grouped in transmission regions to show representative marginal prices by region. The information obtained from the nodal marginal prices in the wholesale power market [64] shows that the transmission network has congestion. The average marginal congestion component (CCM) per year for each region has an upward trend from 2016 to 2019. Figure 6 quantifies the above by illustrating that the CCM in regions such as Cancun increased from 2.23 USD/MWh in 2016 to 34.43 in 2019 and decreased from 0.45 to -32.17 in Hermosillo region in the same period. This means that, in regions with weak connections, such as Cancun, the CCM was a small value in 2016, but in 2019 the CCM was more considerable. Similarly, in nodes with weak connections but a high generation profile, the higher the negative CCM, the more significant congestion. Regions such as Central, Lazaro Cardenas, Aguascalientes and Guadalajara had low CCM due to a more robust transmission zone and the proximity to the reference node, Queretaro. Finally, the CCM decreased in 2020 because there was a general reduction in power production due to the COVID-19 pandemic.

Figure 7 shows the transmission capacity in megawatts between regions in 2017, and the transmission links more congested in 2019, according to CCM presented in Figure 6. Although regions Central, Monterrey, and Guadalajara are the most important load centers, the transmission links more congested are 1-3, 38-41, and 17-24, followed by 2-8, 19-32, and $42-43$, since the difference in CCM related to that links is the largest. This pattern is increased over time, which means that congestion has increased from 2016 to 2019.

Designers considered international public tenders launched by CFE as the primary mechanism for constructing and operating transmission lines. Although transmission and distribution activities remained under the State's control, the federal government, through CFE subsidiaries, was allowed to develop joint ventures with private companies to finance, construct, maintain, operate and expand the transmission and distribution networks. The tariffs for these services are regulated by CRE, as established by the LIE. Since the LIE addressed the rights of permit holders under the old regime, the transmission tariffs make a distinction for grandfathered permit holders and wholesale energy market participants. In either case, the postage-stamp model was implemented. CRE established that the required income for CFE Transmission subsidiary was the expression (2)

$$
R I=C+O M A-X
$$


where $R I$ is the required income, $C$ is the return on capital and depreciation, $O M A$ stands for operating, maintenance and administration costs, and $X$ is an efficient factor. The required income is allocated $70 \%$ to consumers and $30 \%$ to generators, and weighted by the voltage level and the energy related to each generator or consumer [65]. The methodology applied by CRE is the same since 2010. Therefore, the adoption of specialized wheeling tariffs is crucial for incentive, allocation, and cost recovery of transmission and distribution networks [66,67].

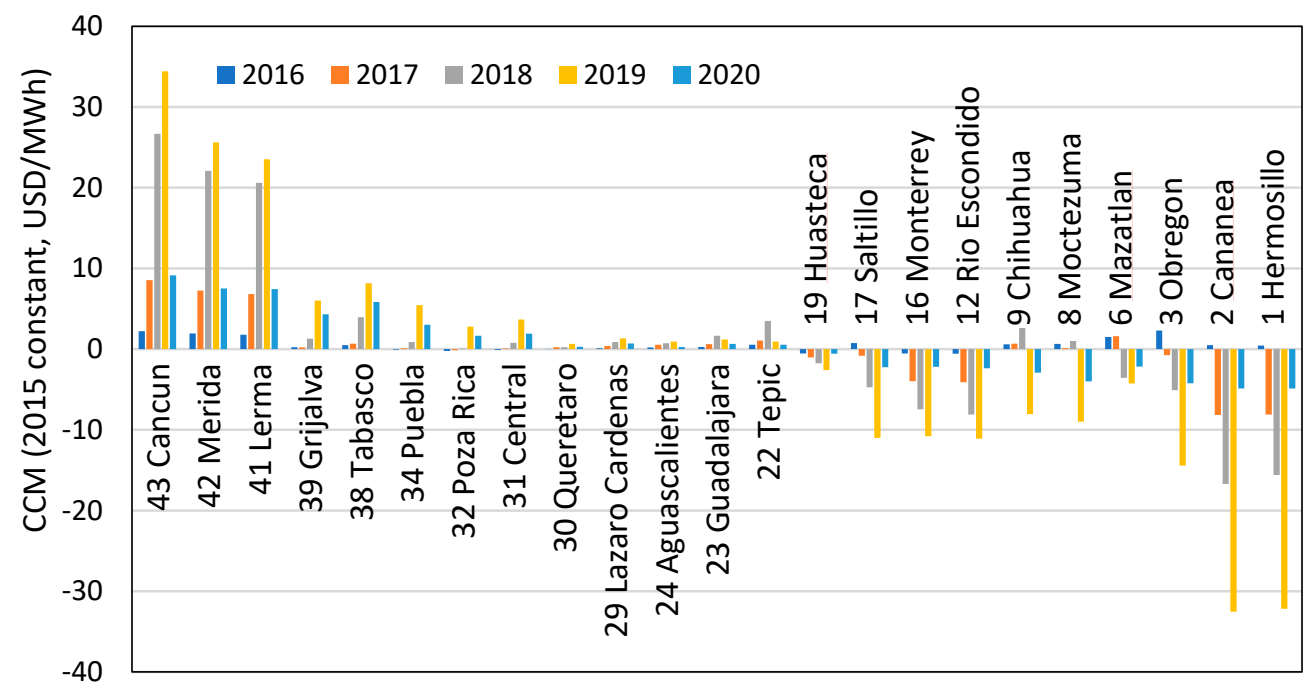

Figure 6. Average yearly CCM for representative transmission regions of the SIN in the period 2016-2020.

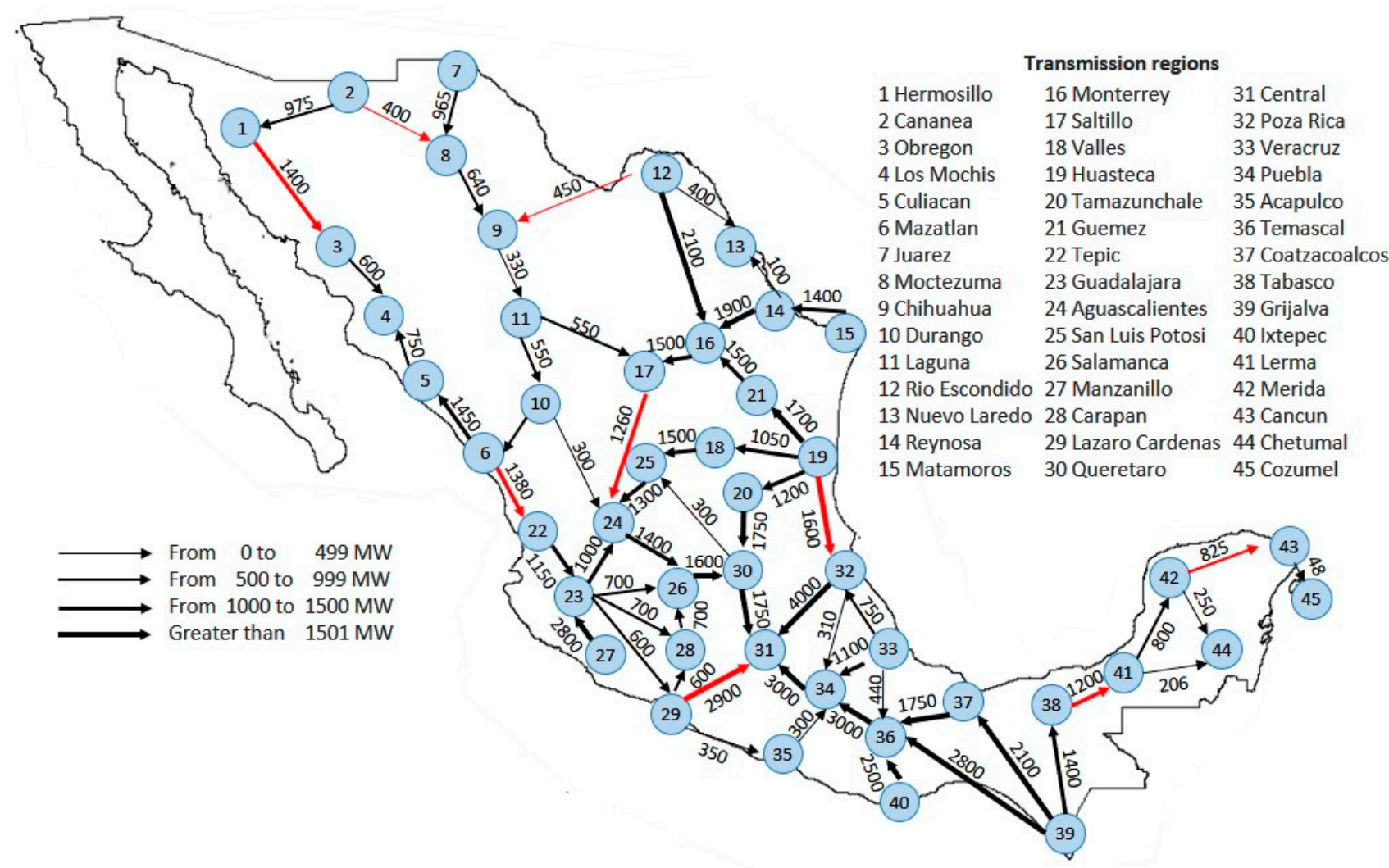

Figure 7. Transmission regions in the Mexican power system links congested in red and transmission capacities in 2017 [62]. 
Regarding CFE's generation subsidiary production companies, Table 4 shows that the average service life of generation equipment is 37 years, with CFE Generacion VI being the subsidiary with the highest average age [63], putting at risk the system's reliability due to the power equipment demanding more frequent maintenance processes. On the other hand, CFE subsidiaries present generation costs well above the IPP, notice that economic loss reaches an average of USD 648 million per year, giving a total of USD 3239.63 million in 2019.

Table 4. Seniority and average cost (2015 constant, USD) of CFE subsidiaries in 2019. * Weighted average cost includes IPP.

\begin{tabular}{ccccc}
\hline Subsidiaries & $\begin{array}{c}\text { Average Age of Plants } \\
\text { (years) }\end{array}$ & $\begin{array}{c}\text { Produced Energy } \\
\text { (GWh) }\end{array}$ & $\begin{array}{c}\text { Average Cost } \\
\text { (USD/MWh) }\end{array}$ & $\begin{array}{c}\text { Economic Loss } \\
\text { (Million USD) }\end{array}$ \\
\hline Totals & & $231,939.20$ & $73.77^{*}$ & 3239.63 \\
\hline CFE Generation I & 36.1 & $24,587.20$ & 94.85 & 510.61 \\
\hline CFE Generation II & 33.5 & $26,324.55$ & 108.02 & 903.18 \\
\hline CFE Generation III & 33.7 & $29,071.01$ & 95.38 & 836.78 \\
\hline CFE Generation IV & 39.8 & $27,102.83$ & 64.81 & 267.16 \\
\hline CFE Generation VI & 41.8 & $32,640.18$ & 107.50 & 722.44 \\
\hline & & IPP & & \\
\hline CFE Generation V & 12.1 & $92,213.42$ & 43.21 \\
\hline
\end{tabular}

Table 5 shows the cost of CFE's inefficiencies. The estimate of CFE's inefficient costs recognized by the CRE was in the order of USD 3078.54 million, with generation being the most significant contributor to such losses. Regarding subsidies, the ASF estimated that, in 2019, the federal government granted a subsidy of USD 5998.89 million, of which the Secretaría de Hacienda y Crédito Público (SHCP) the Treasury Department made a transfer to CFE of USD 3961.85 million. The missing amount was covered by charging CFE's liabilities, affecting the company's finances so that it was not profitable and did not generate economic value for the State.

Table 5. Cost of CFE inefficiencies recognized by the CRE in electricity tariffs.

\begin{tabular}{ccc}
\hline Concept & $\begin{array}{c}\text { Amount } \\
\text { (USD Million) }\end{array}$ & Percentage (\%) \\
\hline Total & 3078.54 & 100.0 \\
\hline Generation & 1636.57 & 53.2 \\
\hline Transmission and distribution & 1389.25 & 45.1 \\
\hline Basic supply & 52.73 & 1.7 \\
\hline Subsidies granted by SHCP to domestic and agricultural users & \\
\hline Estimated total subsidies & 5998.89 & 100 \\
\hline Subsidies granted by SHCP & 3961.85 & 66 \\
\hline Subsidies charged to CFE liabilities & 2037.04 & 34 \\
\hline
\end{tabular}

An objective of the electricity reform was to reduce electricity prices. However, despite the subsidies and the fact that the subsidiaries have shown large losses, most users have not seen a significant reduction in practice, which is why the electricity reform is perceived by society as a deception. Mexicans expected the most significant benefit of the reform to be a reduction in tariffs [68]. 


\subsection{Investment in the Electricity Sector}

One of the main objectives contemplated in the design of the electricity reform was to encourage private investment in the different activities of the sector. In the opening of competitive areas, the injection of capital in generation and commercialization was allowed. In contrast, in regulated areas, incentive mechanisms were required to remedy the lack of capital to carry out the required projects.

The Energy and Infrastructure Investment Trust, also known as Fibra E, is a financial vehicle designed to attract investment in transmission projects that meet specific requirements by negotiating revenue from mature assets. Fibra $\mathrm{E}$ is structured through a Mexican trust fund created to issue senior bonds to be placed and offered through a public offering on the Mexican Stock Exchange. The revenue obtained from the issuance, considering the partial exercise of the over-allotment option, amounted to USD 885 million.

According to the ASF, no amount has been allocated from the proceeds of the senior bonds to execute transmission projects. An unfavorable net financial effect for CFE Transmission is exposed, with USD 123 million at the ending of 2019. The ASF has even issued the recommendation to cancel the trust since it does not generate value for the company [69].

The primary purpose of the Fondo de Servicio Universal Eléctrico (FSUE) the electrification trust fund, as established in Article 115 of the LIE, is to finance electrification actions in rural communities and marginalized urban areas, based on the income from the double collection of losses from the settlement in the operation of the wholesale energy market. The FSUE was created in 2014 and began to receive income from CENACE in 2016. However, it stopped its activities from the beginning of 2019 until the end of the same year. In the period from 2014 to 2019, the fund received contributions for USD 435.47 million mainly from CENACE, of which almost USD 75.42 billion were delivered to the Fideicomiso para el Ahorro de Energía Eléctrica (Mexican Energy-Saving Trust Fund), USD 79.65 million to CFE distribution, 0.75 million were disbursed in consultancies, audits and fiduciary fees. Whereas USD 172.10 million were returned to CENACE due to under-expenditure, USD 15.10 million were contributed to the federal treasury, and USD 9.30 million appear without concept [70]. Besides, the transmission project from Ixtepec to Central with a nominal capacity of $3000 \mathrm{MW}$ was canceled in 2019 [71].

\subsection{Regulatory Capture}

The characteristics and strengths of the regulator are delimited by the powers granted by law. In accordance with the resources allocated to the regulator, their tools are of varying degrees of complexity and scope given the budget, human resources, and experience. In 1993 , the CRE was created to regulate private participation in generation, and its law was published in 1995. The CRE became an independent agency in 2015. The Gilardi index has been used to unofficially determine the independence of the regulator. In 2011, the Comisión Federal de Mejora Regulatoria (Federal Bureau of Regulatory Improvement) used the index to compare some Mexican institutions, with 0.55 being the value reported for the CRE. Subsequently, in 2015, Salazar used the index to compare the CRE's independence before and after the 2013 energy reform, obtaining the value 0.84 [72]. Under the legal framework, the Gilardi index is 0.84 , though CRE has yielded its power following the current federal government, so the index does not reflect the current situation.

Recently, the first negative impact on the CRE was reducing its budget and reducing its workforce. Figure 8 shows the budget reduction in 2019, USD 5 million less than in 2018 [73-78], while the permanent workforce was reduced from 224 to 188 in the referred year [79]. Second, the resignation of five commissioners of the CRE, including the president commissioner, occurred from December 2018 to June 2019, which had never happened before. Subsequently, the election of the commissioners occurred by direct assignment by the head of the Federal Government after the double rejection by the Senate. Likewise, it has been openly stated that the energy policy considers the support of the CFE, a clear signal of reform agnosticism [80]. It is worth noting that the impartiality of the CRE 
commissioners is compromised given their affinity with the current administration, that is why Gilardi's index is assumed to drop below 0.83 (see Table 6). Additionally, the number of CRE commissioners with extensive knowledge of the power sector has severely reduced.

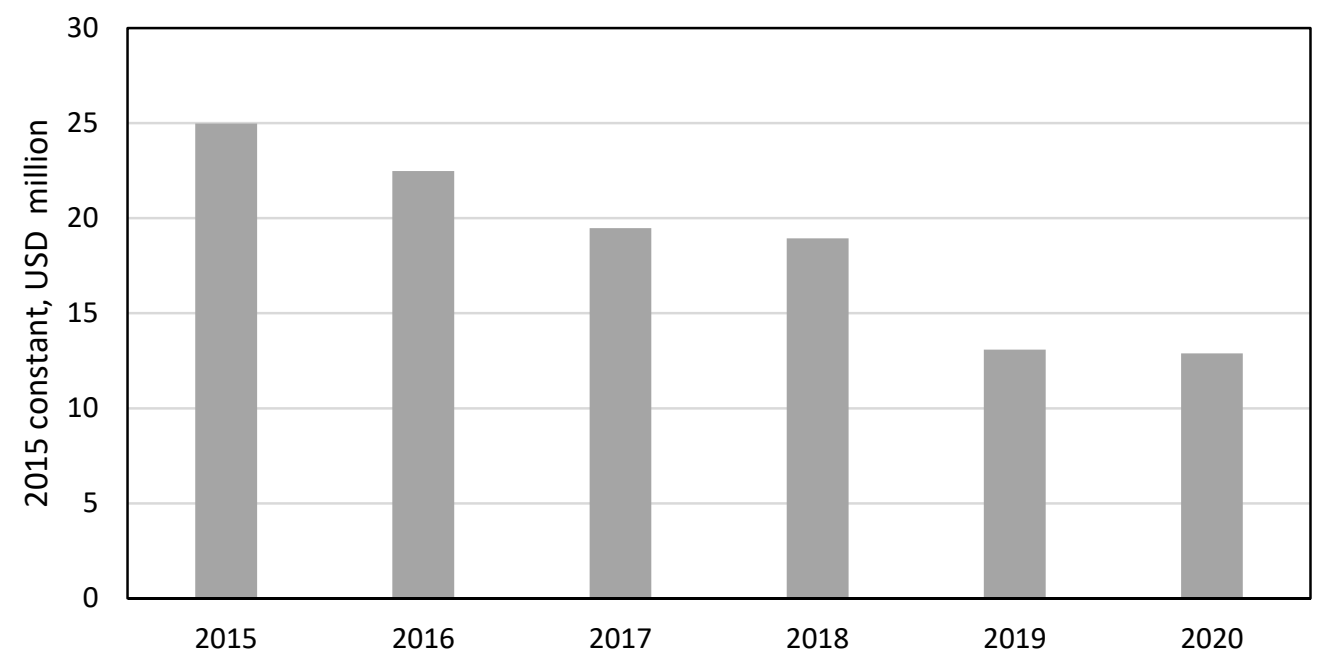

Figure 8. CRE budget allocated by the federal government.

Table 6. Gilardi index applied to the CRE in 2015.

\begin{tabular}{|c|c|c|}
\hline & & Index \\
\hline \multicolumn{3}{|l|}{ Holder status } \\
\hline 1. Term of office & 7 years (Art. 7, LORCME) & 0.80 \\
\hline 2. Who names him? & $\begin{array}{l}\text { The head of the Executive proposes, and the Senate } \\
\text { approves (Art. 7, LORCME) }\end{array}$ & 0.75 \\
\hline 3. Grounds for dismissal & For policy and non-policy reasons (Art. 9, LORCME) & 0.67 \\
\hline $\begin{array}{l}\text { 4. Can the Presiding Commissioner hold other positions within } \\
\text { the government during his or her tenure? }\end{array}$ & No (Art. 8, LORCME) & 1.00 \\
\hline 5. Is it possible to renew the position? & Yes, one-time (Art.7, LORCME) & 0.50 \\
\hline 6. Is independence required for the assignment of the position? & Yes (Art.8, LORCME) & 1.00 \\
\hline \multicolumn{3}{|l|}{ Commission status } \\
\hline 7. Term of office & 7 years (Art. 6, LORCME) & 0.8 \\
\hline 8. Who names him? & $\begin{array}{l}\text { Proposed by the Executive and approved by the } \\
\text { Senate (Art.6 LORCME). }\end{array}$ & 0.75 \\
\hline 9. Grounds for dismissal & For policy and non-policy reasons (Art. 9, LORCME) & 0.67 \\
\hline $\begin{array}{l}\text { 10. Can commissioners hold other positions during their } \\
\text { term of office? }\end{array}$ & No (Art. 8, LORCME) & 1 \\
\hline 11. Is it possible to renew the position? & Yes, one-time (Art.6, LORCME) & 0.5 \\
\hline 12. Is independence required for the assignment of the position? & Yes (Art.8, LORCME) & 1 \\
\hline \multicolumn{3}{|l|}{ Relationship with government and parliament } \\
\hline 13. Is it formally independent from the government? & Yes (Art. 3 LORCME) & 1 \\
\hline 14. What are the obligations to the government? & None & 1 \\
\hline 15. What are the obligations to parliament? & $\begin{array}{l}\text { Submission of an annual report for informational } \\
\text { purposes (Art. } 23 \text { LORCME) }\end{array}$ & 0.67 \\
\hline 16. Who, other than the court, can overrule its decisions? & Nobody & 1 \\
\hline
\end{tabular}


Table 6. Cont

\begin{tabular}{|c|c|c|}
\hline & & Index \\
\hline \multicolumn{3}{|l|}{ Organizational and financial autonomy } \\
\hline 17. What is the origin of the budget? & Regulated activities and Congress (Art. 3 LORCME) & 0.5 \\
\hline 18. How is the budget managed? & $\begin{array}{l}\text { The budget is administered by the agency itself, } \\
\text { subject to approval by the SHCP. (Art. 30, LORCME) }\end{array}$ & 1 \\
\hline 19. Who decides the internal organization of the agency? & Agency (Art. 22, LORCME) & 1 \\
\hline 20. Who is in charge of the agency's personnel policy? & The committe (Art. 23, LORCME) & 1 \\
\hline \multicolumn{3}{|l|}{ Areas of competence to regulate } \\
\hline 21. Tariffs & Agency and government & 0.25 \\
\hline 22. Permits & Only the agency & 1.00 \\
\hline 23. Permit modification & Only the agency & 1.00 \\
\hline 24. Network access & CRE and CENACE & 0.75 \\
\hline 25. Power quality & The CRE & 1.00 \\
\hline 26. Authority to regulate through economic sanctions & Yes & 1.00 \\
\hline Independence Index & & 0.83 \\
\hline
\end{tabular}

The result of these actions was a decrease in the activities attributed to the CRE. The number of permits granted in electricity was reduced in recent years, with only 22 permits in 2020; the percentage of permits granted was reduced by 77\% compared to 2019 (see Table 7).

Table 7. Permits granted by CRE in 2016-2020.

\begin{tabular}{cccccc}
\hline Year & Electricity & Oil & Liquified Petrolum Gas & Natural Gas & Hydrocarbons \\
\hline 2016 & 158 & 1370 & 5269 & 48 & 170 \\
\hline 2017 & 126 & 470 & 235 & 81 & 164 \\
\hline 2018 & 131 & 551 & 398 & 93 & 214 \\
\hline 2019 & 94 & 521 & 280 & 48 & 169 \\
\hline 2020 & 22 & 287 & 213 & 42 & 99 \\
\hline
\end{tabular}

The restructuring of the electricity sector under the textbook model contemplates the ISO's essential function: to guarantee open and non-unduly discriminatory access to the transmission and distribution networks to market participants who request it and comply with specific requirements.

In this regard, according to the Manual for the Interconnection of Power Plants and Connection of Load Centers and base 5 of the wholesale energy market bases, CENACE is responsible for monitoring the connection and interconnection process requested by market participants to connect load centers or interconnect power plants to the SEN, as appropriate.

According to the LIE, the number of studies required to get the approval of CENACE to celebrate the interconnection contract with the transmission company is three for power plants below or equal to $10 \mathrm{MW}$, and four if the power plant is above $10 \mathrm{MW}$. All of them are individual requests. Meanwhile, the application process for plants that opt for planning is not addressed, since the number of plants that opt for this modality is very low compared to that previously mentioned.

CENACE reports interconnection requests, as well as their status, from 2016 to 2020. The number of requests submitted for processing has decreased significantly in recent years, this being 157 in 2020. From the total number of applications, a tiny percentage 
corresponds to planning applications, while the rest corresponds to individual and existing applications. Similarly, requests for contracts and agreements have also decreased significantly, accumulating in 2020 to only 38\% concerning the previous year. Similarly, the number of canceled applications has also decreased. It is essential to highlight that the number of pending applications that have not reached contracts and agreements increases each year concerning the previous one (see Figure 9).

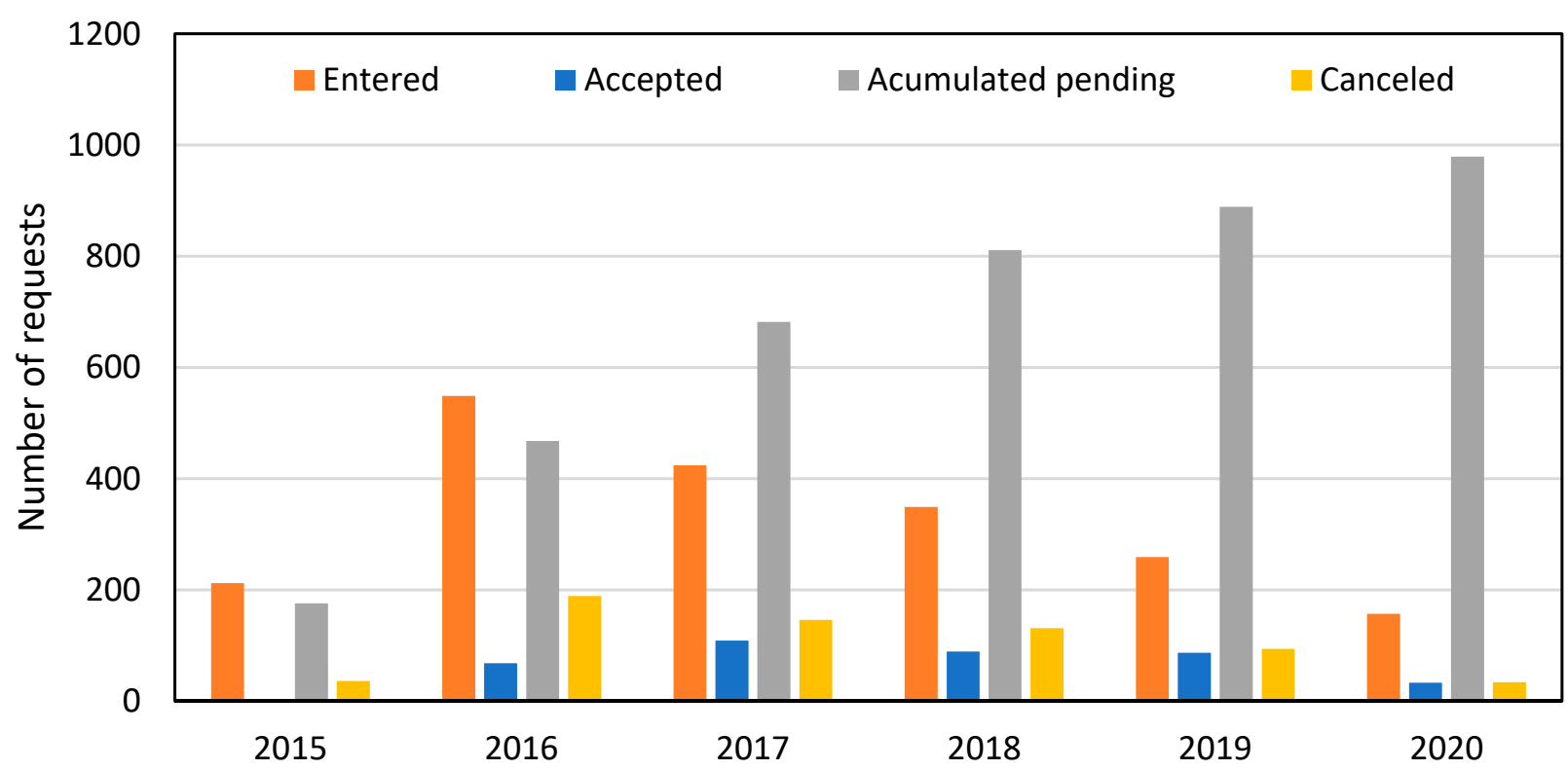

Figure 9. Number of interconnection requests per year from 2015 to 2020.

\subsection{International Agreements}

According to the Economic Ministry, Mexico participates in more than 70 trade agreements with 80 countries. Nevertheless, the United States-Mexico-Canada Agreement and Trans-Pacific Partnership are of great relevance because energy trade and protection to investments are addressed in both of them.

Because of the signing of the North American Free Trade Agreement in 1992, Mexico opened the electricity sector to private participation. Today, with a reform in the process of being reversed, the United States-Mexico-Canada Agreement (USMCA) encourages private participation in the industry and doing so under good regulatory practices and in a sustainable manner. Among the points of the USMCA regarding energy and regulation, the guarantee of investments against direct or indirect expropriation measures by the federal government stands out (chapter 14). It restricts the undue benefit of the federal government in favor of public companies (chapter 22.4) and against private companies. It establishes the option of investor-government arbitration (chapter 14) and State-State arbitration (chapter 31). It promotes good regulatory practices (chapter 22.5) and encourages environmental protection (chapter 24).

Another important agreement is the Comprehensive and Progressive Agreement for Transpacific Partnership [81], reaffirmed in 2018. This agreement includes the nonconforming activities in the annex, which consider the exclusion of some activities nonsubject to liberalization. This means that every activity not included in the non-conforming activities is liberalized and subject to competence rules.

\section{Discussion}

According to the results presented in the previous sections, power sector restructuring was necessary due to the problems faced by the power sector before 2013. It is helpful to set two periods to evaluate the implementation reform, the reform progress period from 2013 to 2018 and the reform reversion period from 2018 to 2021. 


\subsection{Reform from 2013 to 2018}

It should be noted that the reform progress period was short; the constitutional reform took place in 2013, and the wholesale electricity market started operations at the beginning of 2016. As we have shown, the power sector reform followed the textbook model closely, except that privatization did not occur. However, the Federal Government maintained preponderant participation in overseeing the sector through SENER and CRE and kept sector activities through CFE's subsidiaries. The Federal Government held vital aspects, such as the appointment of CRE's commissioners, the executive director of CFE, and the determination of tariffs for specific population groups. Two groups were involved in the reform design (2013-2018), the technical-SENER and the political-Congress. The technical group was devoted to design and propose reform elements seeking technical and economic efficiency. Meanwhile, the political group proposed reform changes seeking non-technical objectives. Moreover, they were in charge of the final approval.

\subsection{Reform Reversion from 2018 to 2021}

The attributions granted to the Federal Government by the original reform design facilitated the reversion of several reform implementations in this period. This reveals that the power sector depends on the administration in office. The energy policy objectives of President López Obrador's administration are based on a vertically integrated sector led by the State companies. Thus, the policy actions taken in the reversion period mean an administrative and structural blockage to the energy market-oriented reform. The CFE basic service supplier is the preponderant market participant still. Private market participation has increased slowly but is yet small. However, the reversion actions hinder the entrance of new participants. Moreover, legacy participants do not have enough incentives for switching from legacy to market modality. The year 2020 was non-typical and the COVID19 pandemic affected electricity consumption globally, and Mexican electricity consumption was also reduced. Other effects of the pandemic included the suspension of administrative activities in the power sector and the extension of procedures indefinitely. The main results of this work can be grouped into four key categories: distorted unbundling; regulatory capture and discriminatory access; lack of investment in transmission.

\subsubsection{Distorted Unbundling}

The vertical separation of the main activities in the electricity industry was established originally in 2016 with the publication of the terms for the strict separation of CFE [57]. Nevertheless, in 2019, the federal government, through SENER, modified the terms for the strict separation of CFE [82], where CFE is allowed to reorganize its assets, arguing that legal separation has reduced the availability and efficiency of power plants and has increased their costs due to the geographical separation of assets for each subsidiary. The modifications allow for the reorganization of generation assets to the discretion of SENER, and share information and personnel for all CFE subsidiaries and affiliates. These modifications have significant implications. The first two are unfair practices for the rest of the participants. At the same time, the last one put more pressure on the federal government finances, prohibiting the entrance of private investment in transmission assets, contrary to art. 30 and 31 in LIE.

\subsubsection{Regulatory Capture}

In 2014, the following CRE characteristics were strengthened: independence, competencies and stability in the long run. The Gilardi index was 0.84 after reform implementation. The missing items to get a higher value were: the appointment and dismissal mechanisms, the relation with the Federal Government and the Congress, the budget source, and some competencies such as tariffs establishment and granting open access to the grid. The independence protection mechanisms were not sufficient to prevent political capture. First, in 2018, the budget was reduced. Second, in 2019, five out of six commissioners resigned before their term of office had expired, and the appointment of new commissioners was by 
the direct nomination of President López Obrador. Likewise, contrary to its competencies, the support of the regulatory bodies has been openly requested for the benefit of the State companies [83]. Under political capture, there is no guarantee that the CRE can exercise other fundamental activities, such as granting permits, determining tariffs objectively, monitoring non-unduly discriminatory access to the grid, and enforce sanctions against market participants. The independent mechanisms of CRE should be revised and strengthened, such as the budget source, the appointment and dismissal of commissioners, and their required competencies.

\subsubsection{Failure in Granting Non-Unduly Discriminatory Access to the Grid}

As a result of the actions against the electricity reform, CENACE has delayed the interconnection studies of power plants, thereby halting the access of new participants to the network. Likewise, derived from the restrictions of activities at the national level due to the COVID-19 pandemic, CENACE issued a statement limiting the entry of variable generation plants, such as solar and wind power plants, for an indefinite period [84]. On the other hand, CRE has been instructed by the Federal Government to not grant permits for new private participants [83]; additionally, LIE has been modified to conditioning the granting of generation permits to PRODESEN expansion plans issued by SENER [10]. This restriction has caused the beginning of legal processes against the Federal Government's actions, and at the time, they are pending Supreme Court decision. Other important counterbalances include the international agreements. International cooperation prevents radical changes and provides stability in the long term. The USMCA and the Transpacific Partnership commit the parties to enforce competence in the established activities, promote good regulatory practices, and restrict the undue benefit of the federal government in favor of public companies.

\subsection{Lack of Investment in Transmission}

The lack of infrastructure in the transmission is reflected by the increase in transmission losses over time and the increase in congestion in some regions of the Mexican power system. The main congested links are Hermosillo-Obregon, Cananea-Moctezuma in the northwest, while in the southeast, the congested links are Merida-Cancun and TabascoLerma. Even though capacity generation significantly exceeds demand, the operating reserve margins are sometimes too low, and the bottleneck in transmission contributes to such a problem. The transmission project outlined after the implementation of electricity reform was canceled. Besides, FSUE and Fibra E, market mechanisms, were underused or not implemented to develop network infrastructure. Moreover, modified terms for the strict separation of CFE [82] canceled the private participation in the transmission projects. Week transmission and distribution networks prevent open access to the grid because individual interconnections will require costly reinforcements to interconnect a power plant to the network.

This work is an empirical analysis of the Mexican power sector reform and focuses on the SIN. The clean energy certificates market and the balancing capacity market were not addressed in this work.

\section{Conclusions}

Almost all of the power systems around the world have gone through different types of reform. The reasons are different: sometimes this is due to the financial situation, the technological evolution of the equipment, or the political situation. In the case of Mexico, the driving reason was the financial situation. The reform included well-accepted practices from the best wholesale electricity markets, with improvement mechanisms. After five years, when the reform was not mature enough, in 2018, President López Obrador started a counter-reform with the issues described in the previous section.

We made a comparative analysis of the textbook model with the power sector reform performed in Mexico to evaluate the implementation depth. We found that the reform 
in 2013 applied the full textbook model, avoiding privatization. The original design granted vast attributions to the Federal Government through SENER, CRE, and CFE. The attributions facilitated that the Federal Government reversed three essential items starting in 2018: vertical unbundling of CFE, horizontal reorganization of CFE generation, and undermined CRE independence. Additionally, the Federal Government modified the LIE to conditioning the access to new entrants for approval from SENER and canceled the obligation of CFE Basic Service Supplier to acquire power under market mechanisms. Currently, the LIE modification is pending the Supreme Court decision, and international agreements are expected to minimize radical changes against the market structure.

The instruments designed to develop transmission and electrification infrastructure, Fibra E and FSUE, were underused, although investment in transmission and distribution infrastructure is much needed. Additionally, the modifed terms for the strict legal separation of CFE closed the possibility to develop, commission, and finance infrastructure with private participation in transmission and distribution. The new government regulation unduly benefits CFE and creates uncertainty for the rest of the participants.

Finally, to mitigate these problems and put the reform on track to achieve the goals of the 2014 reform, and to make the national electric sector more efficient in order to increase the country's international competitiveness, it is imperative to act on the following points: 1. Guarantee true vertical unbundling of CFE subsidiaries; the current structure of CFE prevents non-discriminatory access to the grid and allows monopolistic practices. 2. Restore the CRE independence; provide clear and internationally accepted rules for CRE's budget, the appointment and dismissal of commissioners, and their required competencies. These improvements would increase the confidence of market participants in the regulator and reduce the uncertainty in the power sector. 3 . Establish clear rules for non-discriminatory access and strengthen institutions to enforce this rule; this will increase market participation in competitive activities. 4. Increase investment in network infrastructure; establish mechanisms of efficient network expansion, and allow private participation when the Federal Government could not invest. The implementation of the recommendations presented above is necessary for the evolution and success of the electricity reform. In any case, in the long run, political commitment is also required to avoid the dependence on the electricity industry on the political ideals of the administration in office.

Author Contributions: Conceptualization, A.R.L.-T. and F.A.V.-B.; methodology, J.C.P.-P. and F.A.V.-B.; formal analysis, J.C.P.-P. and A.R.L.-T.; investigation, J.C.P.-P.; writing-original draft preparation, J.C.P.-P. and F.A.V.-B.; writing-review and editing, J.C.P.-P.; supervision, A.R.L.-T. and F.A.V.-B. All authors have read and agreed to the published version of the manuscript.

Funding: This research is a product of the Project 266632 "Bi-National Laboratory on Smart Sustainable Energy Management and Technology Training", funded by the CONACYT SENER Fund for Energy Sustainability (Agreement: S0019 $22014 \neg 01$ ).

Data Availability Statement: Data available in publicly accessible repositories cited in the text. The data presented in this study are openly available.

Conflicts of Interest: The authors declare no conflict of interest.

$\begin{array}{ll}\text { Abbreviations } \\ \text { ASF } & \text { Auditoria Superior de la Federación (Federal Superior Audit Office) } \\ \text { CCM } & \text { Marginal Congestion Component } \\ \text { CENACE } & \text { Centro Nacional de Control de Energía (Energy Control National Center) } \\ \text { CFE } & \text { Comisión Federal de Electricidad (Electricity Federal Company) } \\ \text { CRE } & \text { Comisión Reguladora de Energía (Regulatory Energy Commission) } \\ \text { FSUE } & \text { Fondo de Servicio Universal Eléctrico (Universal Electricity Service Fund) } \\ \text { FTRs } & \text { Financial Transmission Rights } \\ \text { IPP } & \text { Independent Power Producer } \\ \text { ICL } & \text { Intermediación de Contratos Legados (Legacy Contracts) }\end{array}$




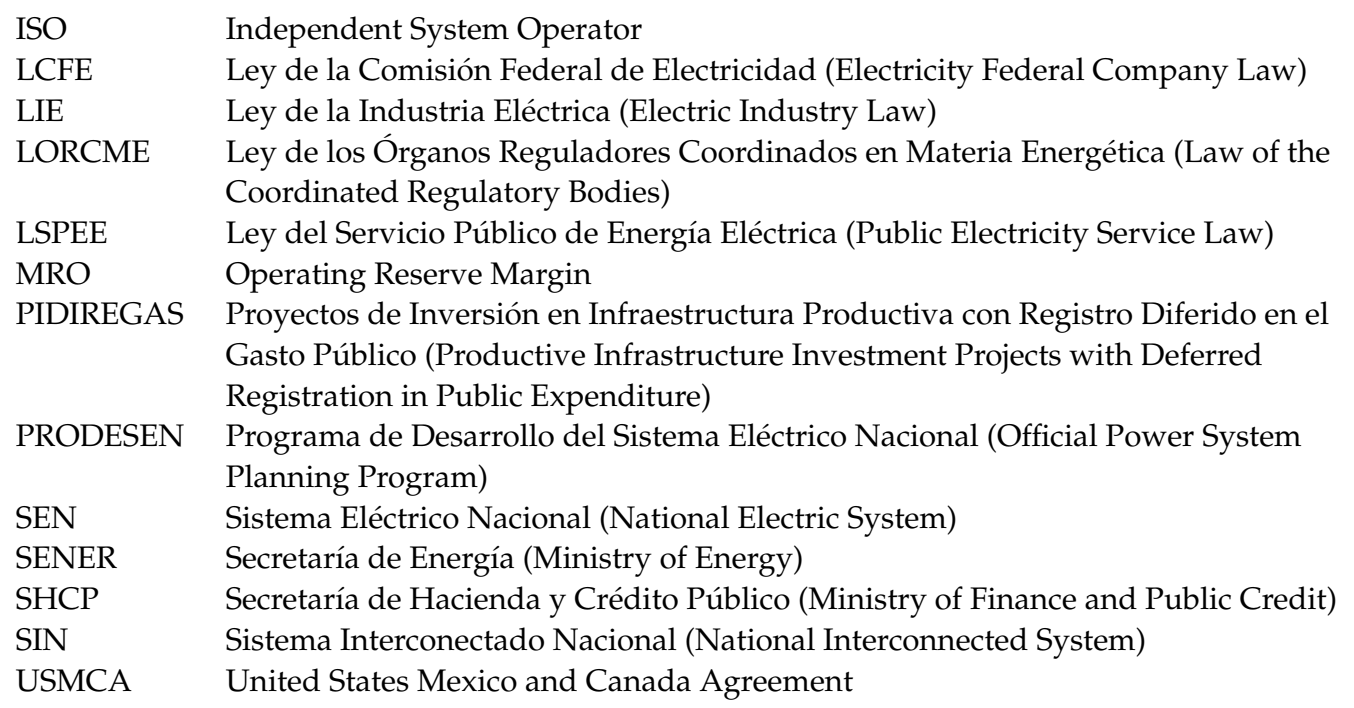

\section{References}

1. Jamasb, T.; Nepal, R.; Timilsina, G.R. A quarter century effort yet to come of age: A survey of electricity sector reform in developing countries. Energy J. 2017, 38. [CrossRef]

2. Sioshansi, F.P. Competitive Electricity Markets: Design, Implementation, Performance; Elsevier: Amsterdam, The Netherlands, 2011; ISBN 0080557716.

3. Robinson, C. Energy Policy: The Return of the Regulatory State. Econ. Aff. 2016, 36, 33-47. [CrossRef]

4. Secretaría de la Economía Nacional Ley de la Industria Eléctrica. Available online: http://www.dof.gob.mx/nota_to_imagen_fs. php?codnota $=4451737 \&$ fecha $=11 / 02 / 1939 \&$ cod_diario=188127 (accessed on 20 May 2021).

5. Congreso de la Unión Ley del Servicio Público de Energía Eléctrica. Available online: http://www.dof.gob.mx/nota_detalle. php?codigo $=4830116 \&$ fecha $=22 / 12 / 1975$ (accessed on 20 May 2021).

6. Congreso de la Unión Decreto que Reforma, Adiciona y Deroga Diversas Disposiciones de la Ley del Servicio Público de Energía Eléctrica. Available online: http:/ / dof.gob.mx/nota_detalle.php?codigo=4705440\&fecha=23/12/1992 (accessed on 20 May 2021).

7. Del Río Monges, J.A.; Rosales Reyes, M.; Ortega Olvera, V.; Maya Hernández, S.O. Análisis de la Reforma Energética; Instituto Belisario Domínguez: Mexico City, Mexico, 2016; ISBN 9786078320561.

8. Presidencia de la República Decreto por el que se Reforman y Adicionan Diversas Disposiciones de la Constitución Política de los Estados Unidos Mexicanos, en Materia de Energía. Available online: http:/ / dof.gob.mx/nota_detalle.php?codigo=5327463\& fecha $=20 / 12 / 2013$ (accessed on 6 December 2020).

9. Cámara de Diputados Ley de la Industria Eléctrica. Available online: https://www.dof.gob.mx/nota_detalle.php?codigo=5355 986\&fecha $=11 / 08 / 2014$ (accessed on 6 December 2020).

10. López Obrador, A.M. Iniciativa con Proyecto de Decreto por la que se Adicionan y Reforman Diversas Disposiciones de la Ley de la Industria Eléctrica. Available online: http:/ /archivos.diputados.gob.mx/portalHCD/archivo/INICIATIVA_PREFERENTE_01 FEB21.pdf (accessed on 23 May 2021).

11. Alpizar-Castro, I.; Rodríguez-Monroy, C. Review of Mexico's Energy Reform in 2013: Background, Analysis of the Reform and Reactions. Renew. Sustain. Energy Rev. 2016, 58, 725-736. [CrossRef]

12. Ibarra-Yunez, A. Energy reform in Mexico: Imperfect unbundling in the electricity sector. Util. Policy 2015, 35, 19-27. [CrossRef]

13. Zenón, E.; Rosellón, J. Optimal transmission planning under the Mexican new electricity market. Energy Policy 2017, 104, 349-360. [CrossRef]

14. Kunz, F.; Rosellón, J.; Kemfert, C. Introduction of nodal pricing into the new mexican electricity market through ftr allocations. Energy J. 2017, 38. [CrossRef]

15. Stoft, S. Power System Economics: Designing Markets for Electricity; Wiley-IEEE Press: Piscataway, NJ, USA, 2002; ISBN 0-471-15040-1.

16. Nepal, R.; Jamasb, T. Reforming small electricity systems under political instability: The case of Nepal. Energy Policy 2012, 40, 242-251. [CrossRef]

17. Bye, T.; Hope, E. Deregulation of electricity markets: The Norwegian experience. Econ. Polit. Wkly. 2005, 40, 5269-5278.

18. Sioshansi, F.P.; Pfaffenberger, W. Electricity Market Reform: An International Perspective; Elsevier: Amsterdam, The Netherlands, 2006; ISBN 0080462715.

19. Bhattacharya, K.; Bollen, M.H.J.; Daalder, J.E. Operation of Restructured Power Systems; Springer Science \& Business Media: New York, NY, USA, 2012; ISBN 1461514657.

20. Hall, D.; Nguyen, T.A. Electricity liberalisation in developing countries. Prog. Dev. Stud. 2017, 17, 99-115. [CrossRef]

21. Sen, A.; Jamasb, T. Diversity in unity: An empirical analysis of electricity deregulation in Indian states. Energy J. 2012, 33. [CrossRef] 
22. Ryu, H.; Kim, Y.; Jang, P.; Aldana, S. Restructuring and Reliability in the Electricity Industry of OECD Countries: Investigating Causal Relations between Market Reform and Power Supply. Energies 2020, 13, 4746. [CrossRef]

23. Litvinov, E.; Zhao, F.; Zheng, T. Electricity Markets in the United States: Power Industry Restructuring Processes for the Present and Future. IEEE Power Energy Mag. 2019, 17, 32-42. [CrossRef]

24. Hobbs, B.F.; Oren, S.S. Three Waves of U.S. Reforms: Following the Path of Wholesale Electricity Market Restructuring. IEEE Power Energy Mag. 2019, 17, 73-81. [CrossRef]

25. Bacon, R.W. Privatization and reform in the global electricity supply industry. Annu. Rev. Energy Environ. 1995, 20, 119-143. [CrossRef]

26. Littlechild, S. Electricity: Regulatory Developments around the World. Available online: https://hepg.hks.harvard.edu/files/ hepg/files/littlechild_12-01_beesley_lect.pdf?m=1523368781 (accessed on 6 December 2020).

27. Joskow, P.L. Lessons learned from electricity market liberalization. Energy J. 2008, 29. [CrossRef]

28. Fotouhi Ghazvini, M.A.; Ramos, S.; Soares, J.; Castro, R.; Vale, Z. Liberalization and customer behavior in the Portuguese residential retail electricity market. Util. Policy 2019, 59, 100919. [CrossRef]

29. Hartley, P.R.; Medlock, K.B.; Jankovska, O. Electricity reform and retail pricing in Texas. Energy Econ. 2019, 80, 1-11. [CrossRef]

30. Shin, K.J.; Managi, S. Liberalization of a retail electricity market: Consumer satisfaction and household switching behavior in Japan. Energy Policy 2017, 110, 675-685. [CrossRef]

31. Urpelainen, J.; Yang, J. Global patterns of power sector reform, 1982-2013. Energy Strateg. Rev. 2019, 23, 152-162. [CrossRef]

32. Bensch, G. The effects of market-based reforms on access to electricity in developing countries: A systematic review. J. Dev. Eff. 2019, 11, 165-188. [CrossRef]

33. Ponce-Jara, M.A.; Castro, M.; Pelaez-Samaniego, M.R.; Espinoza-Abad, J.L.; Ruiz, E. Electricity sector in Ecuador: An overview of the 2007-2017 decade. Energy Policy 2018, 113, 513-522. [CrossRef]

34. Mastropietro, P.; Rodilla, P.; Rangel, L.E.; Batlle, C. Reforming the colombian electricity market for an efficient integration of renewables: A proposal. Energy Policy 2020, 139, 111346. [CrossRef]

35. Daglish, T.; de Bragança, G.G.F.; Owen, S.; Romano, T. Pricing effects of the electricity market reform in Brazil. Energy Econ. 2021, 97, 105197. [CrossRef]

36. Stiglitz, J. Whither reform. In Proceedings of the Keynote Address for the Annual Bank Conference on Development Economics, Washington, DC, USA, 20-21 April 1998; World Bank: Washington, DC, USA, 1999.

37. Brousseau, E.; Glachant, J.-M. New Institutional Economics; Brousseau, E., Glachant, J.-M., Eds.; Cambridge University Press: Cambridge, UK, 2008; ISBN 9780511754043.

38. Majone, G. The rise of the regulatory state in Europe. W. Eur. Polit. 1994, 17, 77-101. [CrossRef]

39. Gilardi, F. Policy credibility and delegation to independent regulatory agencies: A comparative empirical analysis. J. Eur. Public Policy 2002, 9, 873-893. [CrossRef]

40. Mulder, M. Information asymmetry in retail energy markets. In Regulation of Energy Markets; Springer: Cham, Switzerland, 2021; pp. 113-131.

41. Dal Bó, E.; Rossi, M.A. Corruption and inefficiency: Theory and evidence from electric utilities. J. Public Econ. 2007, 91, 939-962. [CrossRef]

42. Nepal, R.; Jamasb, T. Caught between theory and practice: Government, market, and regulatory failure in electricity sector reforms. Econ. Anal. Policy 2015, 46, 16-24. [CrossRef]

43. Larsen, A.; Pedersen, L.H.; Sørensen, E.M.; Olsen, O.J. Independent regulatory authorities in European electricity markets. Energy Policy 2006, 34, 2858-2870. [CrossRef]

44. Ritchie, H.; Roser, M. Energy. Available online: https:// ourworldindata.org/energy (accessed on 10 May 2021).

45. Presidencia de la República Ley del Servicio Público de Energía Eléctrica. Available online: https://www.senado.gob.mx/ comisiones/energia/docs/marco_LSPEE.pdf (accessed on 4 April 2021).

46. SHCP. Proyecto del Presupuesto de Egresos de la Federación 2020. Pidiregas. Available online: https://www.ppef.hacienda.gob. $\mathrm{mx} / \mathrm{es} / \mathrm{PPEF} 2020 /$ pidiregas (accessed on 26 April 2021).

47. SENER. Sistema de Información Energética. Available online: https://sie.energia.gob.mx/bdiController.do?action=temas (accessed on 12 May 2021).

48. CFE. Estados Financieros Consolidados de CFE al 31 de Diciembre de 2017. Available online: https:/ / www.cfe.mx/finanzas / reportes-financieros / Documents / 2017 / CierreE.F.2017.pdf?csf=1\&e=8SjuhD (accessed on 31 March 2021).

49. CFE. Estados Financieros Consolidados Al 31 de Diciembre de 2019, 2018 y 2017. Available online: https://www.cfe.mx/ finanzas / reportes-financieros /Documents/2019/CFEysubs_efc_2019.pdf?csf=1\&e=ESmGFx (accessed on 24 May 2021).

50. CFE. Estados Financieros Consolidados al Cierre de 2016. Available online: https://www.cuentapublica.hacienda.gob.mx/work/ models/CP/2016/tomo/VIII/TVV.05.DAR.pdf (accessed on 24 May 2021).

51. CFE. Estados Financieros Consolidados por los Años que Terminaron el 31 de Diciembre de 2013 y 2012. Available online: https: //www.cuentapublica.hacienda.gob.mx/work/models/CP/2014/tomo/VII/TOQ/TOQ.05.DAR.pdf (accessed on 24 May 2021).

52. CFE. Estados Financieros Consolidados por los Años que Terminaron el 31 de diciembre de 2015 y 2014. Available online: https: // www.cuentapublica.hacienda.gob.mx/work/models/CP/2015/tomo/VIII/TOQ.05.DAR.pdf (accessed on 24 May 2021).

53. CFE. Informe Anual Comisión Federal de Electricidad 2016. Available online: https://www.cfe.mx/finanzas/reportesfinancieros/InformeAnualDocumentos/InformeAnual2016CFE.pdf?csf=1\&e=eUcCiv (accessed on 24 May 2021). 
54. CFE. Informe Anual Comisión Federal de Electricidad 2017. Available online: https://www.cfe.mx/finanzas/reportesfinancieros/Informe\%20Anual\%20Documentos/InformeAnual2017_CFE_vF-031018.pdf?csf=1\&e=pGmKXe (accessed on 24 May 2021).

55. SENER. Prospectiva del Sector Eléctrico 2017-2031. Available online: https://www.gob.mx/cms/uploads/attachment/file/2843 45/Prospectiva_del_Sector_El_ctrico_2017.pdf (accessed on 6 December 2020).

56. Cámara de Diputados Ley de la Comisión Federal de Electricidad. Available online: https://www.dof.gob.mx/nota_detalle.php? codigo=5355990\&fecha=11/08/2014\#: \{\}:text=DECRETO $\% 20$ por $\% 20$ el $\% 20$ que $\% 20$ se, de $\% 20$ Obras $\% 20$ P $\%$ C3\%BAblicas $\% 20 y \%$ 20Servicios (accessed on 6 December 2020).

57. SENER. Términos para la Estricta Separación Legal de la Comisión Federal de Electricidad. Available online: http:/ /www.dof. gob.mx/nota_detalle.php?codigo=5422390\&fecha=11/01/2016 (accessed on 21 March 2021).

58. CENACE. Resultados DFT Legados. Available online: https://www.cenace.gob.mx/Paginas/SIM/ResultadosDFTLeg.aspx (accessed on 6 December 2020).

59. Garcia Sanchez, G.J. Las Letras Pequeñas de la Reforma Energética de México (Spanish edition of The Fine Print of the Mexican Energy Reform). La Nueva Reforma Energética México; Duncan, W., Ed.; Mexico Institute, Woodrow Wilson Internation Center for Scholars: Washington, DC, USA, 2018; pp. 18-62.

60. CENACE. Disponibilidad de Entrega Física. Available online: https://www.cenace.gob.mx/Paginas/SIM/DispEntregaFisica. aspx (accessed on 25 May 2021).

61. CENACE. Capacidad Demandada y RAP. Available online: https://www.cenace.gob.mx/Paginas/SIM/CapacidadDemandadaRAP. aspx (accessed on 25 May 2021).

62. SENER. Programa de Desarrollo del Sistema Eléctrico Nacional 2018-2032. Available online: https://www.gob.mx/cms/ uploads/attachment/file/331770/PRODESEN-2018-2032-definitiva.pdf (accessed on 26 March 2021).

63. ASF. CFE Corporativo: Desempeño de la Comisión Federal de Electricidad. Available online: https://www.asf.gob.mx/Trans/ Informes/IR2019b/Documentos / Auditorias/2019_0431_a.pdf (accessed on 6 December 2020).

64. CENACE. Precios Marginales Locales. Available online: https://www.cenace.gob.mx/Paginas/SIM/Reportes/PreciosEnergiaSisMEM. aspx (accessed on 22 April 2021).

65. CRE. ACUERDO Núm. A/045/2015. Available online: https://www.cfe.mx/industria/tarifas/Documents/Acuerdo\%20A-0452015\%20Tarifas\%20de\%20Transmisi\%C3\%B3n\%20enero\%202016\%20a\%20diciembre\%202018.pdf (accessed on 14 May 2021).

66. Bashian, A.; Hojat, M.; Javidi, M.H.; Golmohamadi, H. Security-Based Tariff for Wheeling Contracts Considering Fair Congestion Cost Allocation. J. Control. Autom. Electr. Syst. 2014, 25, 368-380. [CrossRef]

67. Olmos, L.; Pérez-Arriaga, I.J. A comprehensive approach for computation and implementation of efficient electricity transmission network charges. Energy Policy 2009, 37, 5285-5295. [CrossRef]

68. Pascual, C.; Victor, D.G.; de Castro Medinas, R.F. Will Mexican Energy Reform Survive Political Transition? What Mexicans Think; Brookings Institution: Washington, DC, USA, 2018.

69. ASF. Informe del Resultado de la Fiscalización Superior de la Cuenta Pública 2019: CFE Fibra E. Available online: https: //informe.asf.gob.mx/Documentos/Auditorias/2019_0429_a.pdf (accessed on 11 January 2021).

70. Subsecretaría de Electricidad, S. Estados Financieros FSUE 2014-2019. Available online: https://base.energia.gob.mx/dgaic/da/ q/subsecretariaelectricidad/fondoserviciouniversalelectrico/sener_07_reglasoperacionfondoserviciouniversalelectrico.pdf (accessed on 11 January 2021).

71. CFE. Cancelación del Concurso Abierto No. CFE-0036-CASOA-0001-2018. Available online: http://dof.gob.mx/nota_detalle. php? codigo $=5549643 \&$ fecha $=05 / 02 / 2019$ (accessed on 25 May 2021).

72. García, J.; Marín, R. Mercados y Sostenibilidad para un Sector Energético Competitivo; Editorial Aranzadi, SA: Barcelona, Spain, 2015; ISBN 978-84-9099-357-6.

73. SHCP. Presupuesto de Egresos de la Federación para el Ejercicio Fiscal 2020. Available online: https://www.dof.gob.mx/nota_ detalle.php? codigo $=5581629 \&$ fecha $=11 / 12 / 2019$ (accessed on 4 April 2021).

74. SHCP. Presupuesto de Egresos de la Federación para el Ejercicio Fiscal 2015. Available online: http://www.dof.gob.mx/nota_ detalle.php? codigo $=5374053 \&$ fecha $=03 / 12 / 2014$ (accessed on 11 January 2021).

75. SHCP. Presupuesto de Egresos de la Federación para el Ejercicio Fiscal 2016. Available online: http://dof.gob.mx/nota_detalle. php? codigo $=5417699 \&$ fecha $=27 / 11 / 2015$ (accessed on 11 January 2021).

76. SHCP. Presupuesto de Gresos de la Federación para el Ejercicio Fiscal 2017. Available online: https://www.dof.gob.mx/nota_ detalle.php? codigo $=5463184 \&$ fecha $=30 / 11 / 2016$ (accessed on 11 January 2021).

77. SHCP. Presupuesto de Egresos de la Federación para el Ejercicio Fiscal 2018. Available online: http://www.dof.gob.mx/nota_ detalle.php? codigo=5506080\&fecha=29/11/2017 (accessed on 11 January 2021).

78. SHCP. Presupuesto de Egresos de la Federación para el Ejercicio Fiscal 2019. Available online: http:/ /dof.gob.mx/nota_detalle. php? codigo $=5547479 \&$ fecha $=28 / 12 / 2018$ (accessed on 11 January 2021).

79. CRE. Informe de Labores 2019. Available online: https://www.gob.mx/cms/uploads/attachment/file/544126/CRE_Informe_ de_Labores_2019.pdf (accessed on 16 December 2020).

80. Poder Ejecutivo Federal Iniciativa de reforma de la Ley de la Industria Eléctrica. Available online: https://www.senado.gob.mx/ comisiones/energia/docs/reforma_energetica/dictamen2.pdf (accessed on 22 February 2021). 
81. Presidencia de la República Decreto Promulgatorio del Tratado Integral y Progresista de Asociación Transpacífico, Hecho en Santiago de Chile, el Ocho de Marzo de Dos Mil Dieciocho. Available online: https: / /dof.gob.mx/nota_detalle.php?codigo=5545 $130 \&$ fecha $=29 / 11 / 2018 \&$ print $=$ true (accessed on 25 March 2021).

82. SENER. Acuerdo por el que se Modifican los Términos para la Estricta Separación Legal de la Comisión Federal de Electricidad, Publicados el 11 de Enero de 2016. Available online: https: / /www.dof.gob.mx/nota_detalle.php?codigo=5555005\&fecha=25/03/ 2019 (accessed on 24 March 2021).

83. López Obrador, A.M. Memorandum a Servidores Públicos e Integrantes de los Órganos Reguladores del Sector Energético. Available online: https:/ / energiahoy.com/wp-content/uploads/2020/08/MEMORA\%CC\%81NDUM-2020.pdf (accessed on 25 May 2021).

84. CENACE. Acuerdo de Confiabilidad por el Virus SARS-Cov2 (COVID-19). Available online: https://www.cenace.gob.mx/Docs/ 16_MARCOREGULATORIO/SENyMEM/(Acuerdo\%202020-05-01\%20CENACE)\%20Acuerdo\%20para\%20garantizar\%201a\% 20eficiencia,\%20Calidad,\%20Confiabilidad,\%20Continuidad\%20y\%20seguridad.pdf (accessed on 28 April 2021). 